\title{
Meso- $\beta$ to $-\gamma$-Scale Wind Circulations Associated with Precipitating Clouds near Baiu Front Observed by the MU and Meteorological Radars
}

\author{
By Yoshiaki Shibagaki \\ Osaka Electro-Communication University, Neyagawa, Osaka 572-8530, Japan \\ Manabu D. Yamanaka ${ }^{1}$ \\ Radio Atmospheric Science Center, Kyoto University, Uji, Kyoto 611-0011, Japan \\ Shuji Shimizu ${ }^{2}$, Hiroshi Uyeda \\ Department of Geophysics, Hokkaido University, Sapporo 060-0810, Japan \\ Akira Watanabe \\ Faculty of Education, Fukushima University, Fukushima 960-1296, Japan. \\ Yasuyuki Maekawa \\ Osaka Electro-Communication University, Neyagawa, Osaka 572-8530, Japan \\ and \\ Shoichiro Fukao
}

Radio Atmospheric Science Center, Kyoto University, Uji, Kyoto 611-0011, Japan

(Manuscript received 25 March 1998, in revised form 30 November 1999)

\begin{abstract}
During the Baiu season (17 June-8 July 1991) we carried out simultaneous tropospheric observation by using the MU (Middle and Upper atmosphere) radar (VHF band, Kyoto University) and meteorological radars ( $\mathrm{C}$ band of Osaka Meteorological Observatory, $\mathrm{X}$ band of Hokkaido University and $\mathrm{C} / \mathrm{Ku}$ band of Kyoto University). Vertical distributions of three components of wind field and precipitation particles were observed by the MU and $\mathrm{C} / \mathrm{Ku}$-band radars, respectively. The $\mathrm{C}$ - and $\mathrm{X}$-band radars were used to investigate horizontal distributions of precipitating clouds in the meso- $\alpha$ and $-\beta$ scales, respectively. Several meso- $\beta$ and $-\gamma$-scale cloud systems were observed around a meso- $\alpha$-scale cyclone center during 4-5 July when rainfall was the strongest in the whole observational period. They were divided into two groups of convective clouds i) near a surface warm front and ii) near a surface cold front, and iii) one group of
\end{abstract}

Corresponding author: Yoshiaki Shibagaki, Osaka Electro-Communication University, Neyagawa-shi, Osaka 572-8530, Japan. E-mail: sibagaki@maelab.osakac.ac.jp

1 Present affiliation: Graduate School of Science and Technology, Kobe University, Kobe 657-8501, Japan

2 Present affiliation: National Space Development Agency of Japan, Tokyo, 106-0032, Japan (C) 2000, Meteorological Society of Japan 
stratiform clouds on the north-western side of the surface cold front. In i), a remarkable updraft inside a precipitating cloud extending up to an altitude of $14 \mathrm{~km}$ was produced by a convergence (inflows coming from the front and rear of the precipitating cloud) at an altitude of $4-5 \mathrm{~km}$ and by strong southerly wind in the middle troposphere. In ii), a narrow rainband with gust front was seen at the leading edge of the surface cold front. Two meso- $\gamma$-scale rotor circulations were found in front of and inside the rainband, respectively. In iii), south-easterly (north-westerly) ascent (descent) flows were observed above (inside/under) the cold frontal surface extending up to an altitude of about $9 \mathrm{~km}$. Below the cold frontal surface, there was a dry region without precipitation, and a part of the descending westerly flow returned to the back of the precipitating cloud. In this study, vertical structures of meso- $\beta$ and $-\gamma$-scale cloud systems with characteristic wind flows as mentioned above were revealed by the detailed three components of wind field in both clear and precipitating atmosphere. They were presented as smaller cloud systems in the hierarchical structure of cloud clusters near the meso- $\alpha$-scale cyclone in the central region of the Japan Islands.

\section{Introduction}

A quasi-stationary subtropical front called the Baiu front, appears over a region including southern China and Japan in early summer. It is frequently accompanied by a meso- $\alpha$-scale cyclone, of which distribution of active cloud clusters is inhomogeneous and this makes heavy rainfalls much localized. Movements and evolutions of cloud systems near the meso- $\alpha$-scale disturbance were reported by many studies based on satellite data (e.g., Akiyama 1984; Ogura et al. 1985; Ninomiya et al. 1981, 1988a; Iwasaki and Takeda 1989), but continuous highresolution tracking of each system was impossible. By using C-band meteorological radar of the Japan Meteorological Agency (JMA), Ogura et al. (1985) investigated a cloud cluster that changed from line to blob structure in front of a meso- $\alpha$-scale disturbance. It remained stationary over Nagasaki due to an orographic effect for several hours which included a very heavy rainfall. Ninomiya et al. (1988a, b) also studied the formation of a meso- $\alpha$-scale cloud system using similar meteorological radars, and showed that it was composed of meso- $\beta$ and $-\gamma$-scale cloud systems at the rear of a meso- $\alpha$-scale disturbance in the west region of the Japan Islands.

Recently, kinematic structures of the meso- $\beta$ and - $\gamma$-scale cloud systems have been studied by meteorological radar with Doppler capability. "A Study of Mechanism and Prediction on Heavy Rainfalls during Rainy Season in Japan" project was carried out around Kyushu during the Baiu season in 1988 (Asai 1990). In the experiment, cloud clusters developed by the low-level convergence due to a gust front were shown with single X-band Doppler radar observations by Takahashi et al. (1996). Ishihara et al. (1995) reported dynamical features of rainband similar to a squall line of midlatitude or tropical regions by using a dual X-band Doppler radar system. However, these meteorological Doppler radar observations are completely limited in the region where precipitating echo exists. On the other hand, a clearair radar of the VHF band can observe continuously three components of wind field (including the vertical velocity) of higher resolution irrespective of the weather condition (Röttger and Larsen 1990; Gage 1990). Since it is a vertically pointing radar, a wind distribution in the horizontal plane is localized, and in data analysis we cannot distinguish horizontal and temporal variations of the mesoscale systems. Therefore, the detailed structure and dynamics of a cloud system is revealed only by simultaneous observations using both the clear-air and meteorological Doppler radars.

We performed a three-week observation (17 June8 July 1991) by using the MU (Middle and Upper atmosphere) radar (VHF band), meteorological radars (C, $\mathrm{X}$ and $\mathrm{Ku}$ bands), radiosondes at the MU observatory and rawinsondes of JMA stations (Shibagaki et al. 1996, 1997; Yamanaka et al. 1996). During the three weeks, we confirmed meso- $\alpha$-scale variations of meridional and zonal winds and found meso- $\beta$ and $-\gamma$-scale convective motions restricted by the level of lowest stratiform turbulence near the tropopause level (LSTT) and the frontal surface near the meso$\alpha$-scale cyclone. The results of the MU radar were mainly compared with the vertical structure of precipitating cloud observed by a vertically pointing Cband radar at the $\mathrm{MU}$ observatory. In this paper we analyze several meso- $\beta$ and $-\gamma$-scale precipitating cloud systems observed near a meso- $\alpha$-scale cyclone center that passed the central region of the Japan Islands during 4-5 July. The strongest rainfall on the surface during the whole observational period was observed in this period. We investigate three components of wind field inside the precipitating clouds and the region without any precipitation.

In Section 2, we summarize the simultaneous observations. In Section 3, the synoptic-scale environment and the evolution of the meso- $\alpha$-scale cyclone are described. In Section 4, a meso- $\beta$-scale convective cloud system and meso- $\gamma$-scale motions near the surface warm front are analyzed. In Section 5, we investigate a narrow rainband with a gust front structure near the surface cold front. In Section 6, some features of wind variations near the cold frontal surface (on the north-western side of the surface cold front) are demonstrated. In Section 7, we propose a model of the hierarchical structure from the meso- $\alpha$ 
to $-\gamma$-scale cloud system near the meso- $\alpha$-scale cyclone. Finally, in Section 8 we describe conclusions of this investigation.

\section{Observational system}

The MU radar of the Radio Atmospheric Science Center (RASC), Kyoto University receives echoes scattered from turbulence and water vapor, and provides vertical profiles of three components including vertical motion of the wind field. The time and height resolutions are $\sim 1 \mathrm{~min}$ and $150 \mathrm{~m}$, respectively (Fukao et al. 1985b, c, 1990, 1991). We developed a new spectral fitting method near the bright band at an altitude of $4-5 \mathrm{~km}$ in order to remove effects of precipitation echoes in the vertical velocity estimation, and made a complete data set at intervals of $\sim 3 \mathrm{~min}$ for an altitude range of $2-24 \mathrm{~km}$ from two observation modes with different altitude ranges $^{1}$ (Shibagaki et al. 1997).

Three meteorological radars, C-band (5.3 GHz) radar of Osaka District Meteorological Observatory (OMO) of JMA, X-band $(9.4 \mathrm{GHz})$ radar (included Doppler capability) of Hokkaido University and $\mathrm{C} / \mathrm{Ku}$-band $(5.3 / 13.9 \mathrm{GHz})$ radar of Kyoto University were used in a three-week observation campaign. The latter two were operated simultaneously in the MU observatory during the three weeks. The observational situation of these multi-frequency radars is shown in Fig. 1.

The C-band (OMO) and X-band radars can observe horizontal distributions of precipitating clouds in roughly meso- $\alpha$ (about $500 \mathrm{~km}$ horizontal range) and $-\beta$ (about $120 \mathrm{~km}$ horizontal range) scales, respectively. We used mainly the X-band radar data within a $30-\mathrm{km}$ radius from the radar site for comparison with the MU radar data in detail.

The MU and $\mathrm{C} / \mathrm{Ku}$-band radars can measure vertical distributions of precipitation. Information of the precipitation echo of the MU data is available for the estimation of the drop-size distribution (DSD) in the precipitating cloud (e.g., Wakasugi et al. 1986, 1987; Sato et al. 1990), and only the vertical distribution of the precipitation echoes is discussed in this study. The top level of the precipitation echoes may be almost coincident with the melting layer or so-called bright band altitude (a layer with temperature $\sim 0^{\circ} \mathrm{C}$ ) inside a stratiform cloud, whereas the precipitation echoes above the freezing level may be produced by solid precipitation particles with large fall velocities, which had grown in strong updrafts.

Although information on the melting process of precipitation particles near the bright band altitude may be obtained by comparing echoes between the two bands in the $\mathrm{C} / \mathrm{Ku}$-band radar, the $\mathrm{C}$-band

1 During the three weeks, the MU radar had three (troposphere-stratosphere-mesosphere) observation modes at intervals of $\sim 1 \mathrm{~min}$.

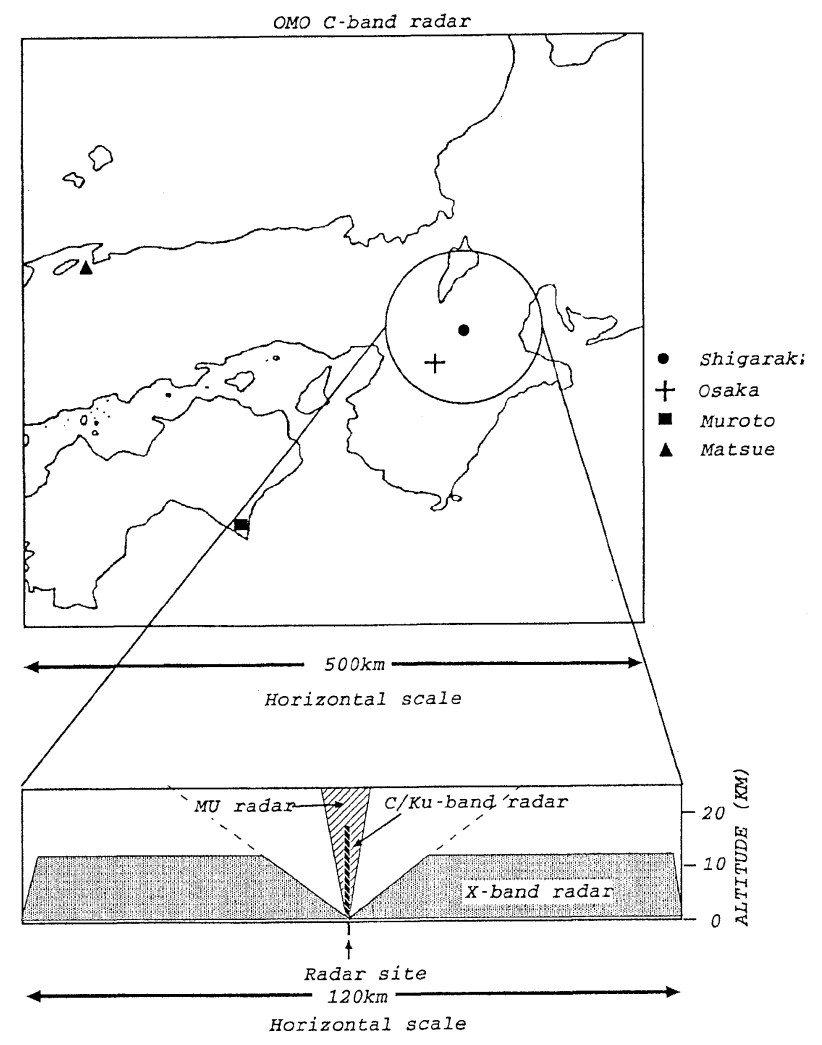

Fig. 1. Observational situation and range of the multi-frequency radars. The OMO C-band radar produces synthesizing radar echoes extended over about $500 \mathrm{~km}$ range observed at three stations; Osaka-Mt. Takayasu $\left(34.61^{\circ} \mathrm{N}\right.$, $\left.135.66^{\circ} \mathrm{E}\right)$, Muroto $\left(33.25^{\circ} \mathrm{N}, 134.18^{\circ} \mathrm{E}\right)$ and Matsue $\left(35.54^{\circ} \mathrm{N}, 133.10^{\circ} \mathrm{E}\right)$. The $\mathrm{X}$-band and the $\mathrm{C} / \mathrm{Ku}$-band radars are located at the MU observatory $\left(34.85^{\circ} \mathrm{N}\right.$, $\left.136.10^{\circ} \mathrm{E}\right)$.

radar data is mainly used here because its attenuation due to rainfall is relatively small. The Cband radar data is compared with the wind fields observed by the MU radar, except for the case near the surface warm front.

During this observational period, intervals of radiosondes launched at the MU observatory are normally about 12 hours. When mesoscale disturbances approached the radar site, the interval was reduced to about 6 hours. Referring to the large gradient level of the equivalent potential temperature analyzed from the radiosonde data at the MU site and the rawinsonde data of JMA, the frontal surface over the MU radar is defined mainly by the vertical shear of horizontal wind (see Shibagaki et al. 1997). For all data, we use the altitude from the mean sea level (MSL), and the MU observatory is at $385 \mathrm{~m} \mathrm{MSL}$. 

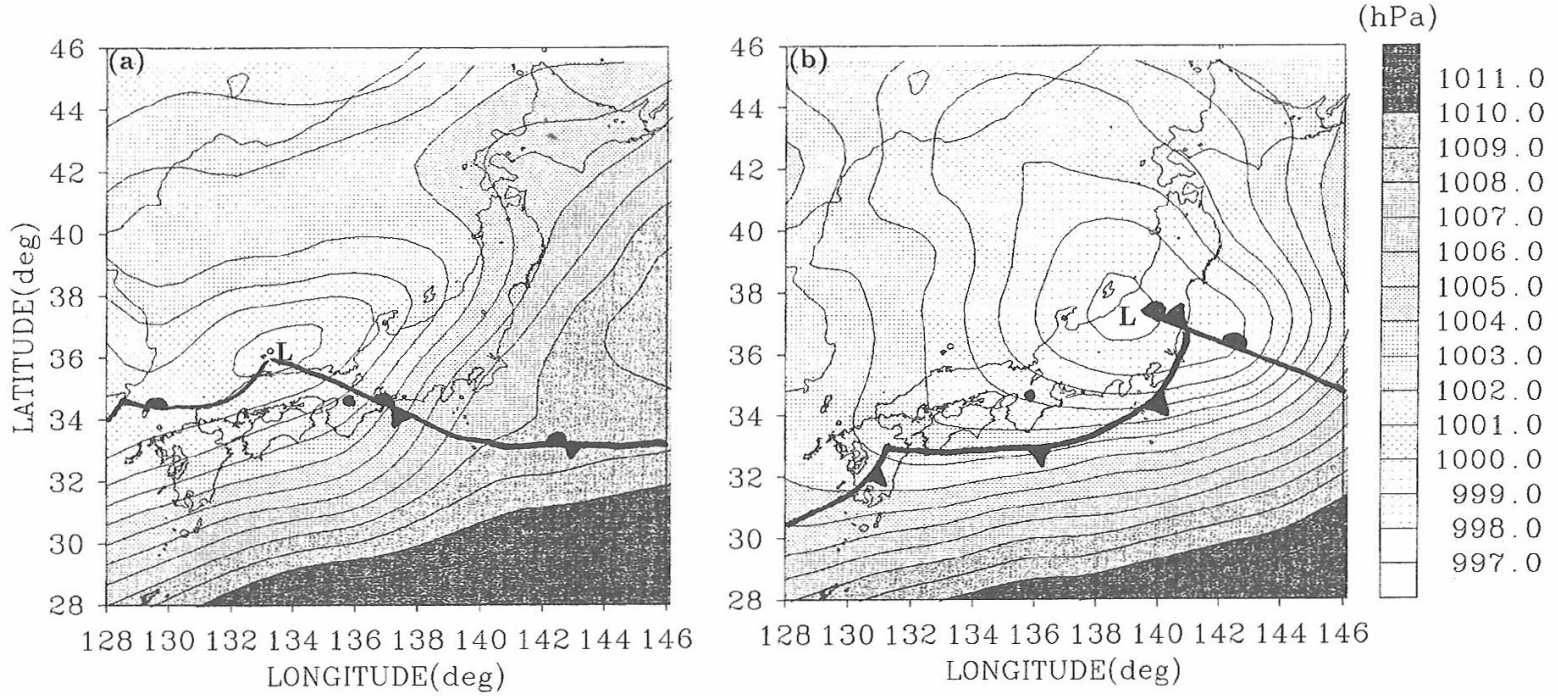

Fig. 2. The horizontal distribution of the surface pressure with JANAL produced by JMA at (a) 2100 LST 4 and (b) 0900 LST 5 July, 1991. Black points are a position of the MU observatory.
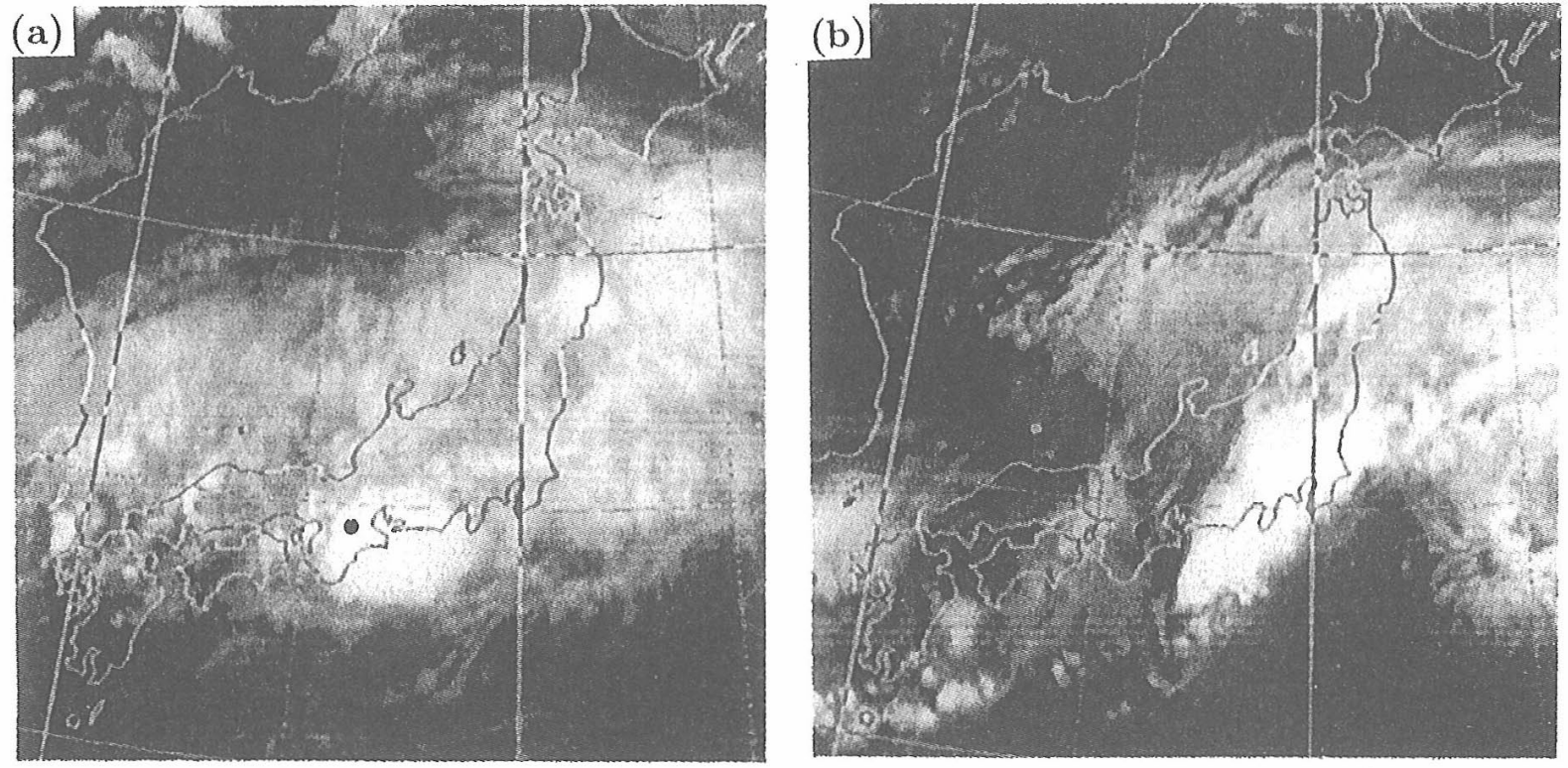

Fig. 3. The horizontal distribution of the cloud cluster with GMS IR images at (a) 2100 LST 4 and (b) 0900 LST 5 July, 1991. Black points are the MU observatory.

\section{Meso- $\alpha$-scale features}

Figures 2 and 3 show horizontal distributions of surface pressure based on Japan regional objective analysis (JANAL) and clouds based on Geostationary Meteorological Satellite (GMS) IR images at 2100 LST 4 and 0900 LST 5 July, 1991, both of which were originally analyzed by JMA. The surface pressure of the meso- $\alpha$-scale cyclone center was $1000 \mathrm{hPa}$ at $2100 \mathrm{LST} 4$, and decreased with eastward movement. It became $998 \mathrm{hPa}$ at $0900 \mathrm{LST} 5$, and the stationary front was deformed to an occluded front. In Fig. 3a a meso- $\alpha$-scale cloud cluster, of which the area of $T_{B B}$ (the area-mean equivalent black body temperature) lower than $-52^{\circ} \mathrm{C}$ is over $4.2 \times 10^{4} \mathrm{~km}^{2}(280 \times 150 \mathrm{~km})$, is located near the stationary front on the south-eastern side of the cyclone center. The characteristic area is smaller than the maximum region $\left(\geq 5 \times 10^{4} \mathrm{~km}^{2}\right.$, for $T_{B B} \leq$ $-52^{\circ} \mathrm{C}$ ) of a mesoscale convective complex (MCC) defined by Maddox (1980). It consisted of some meso- $\beta$ and $\gamma$-scale clouds (see Fig. 5 shown later). Since the stationary front in front of the cyclone center in Fig. 2a extends south-eastward due to the warm airmass from south, it is called here the surface warm front. In Fig. $2 \mathrm{~b}$ we can see clearly the surface warm front with the developing cyclone cen- 


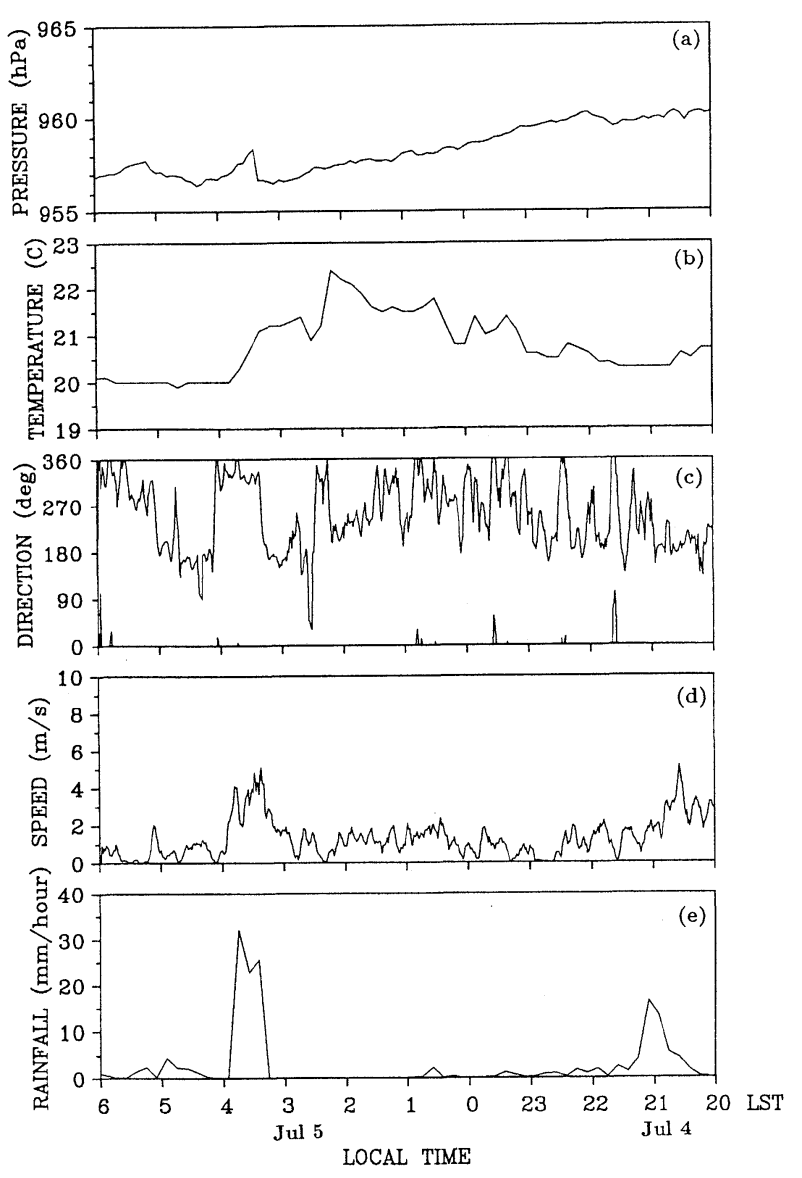

Fig. 4. Surface meteorological data of (a) pressure, (b) temperature, (c) wind direction, (d) wind speed and (e) rainfall intensity at the MU observatory between 2000 LST 4-0600 LST 5, 1991.

ter. In Fig. 3b cloud clusters were distributed on the northern side of the surface warm front, in the vicinity of the cyclone center and along the surface cold front. From a band-like structure obtained by the OMO C-band radar (see Fig. 10 shown later) the time when the surface cold front in Fig. 2b passed over the radar site is estimated at around 0330 LST 5.

Figure 4 shows results of surface meteorological observations at the MU observatory around the passage of the meso- $\alpha$-scale cyclone during the period of 2000 LST 4-0600 LST 5. Temperature increased in the warm sector region between the surface warm and cold fronts. Pressure decreased with the passage of the cyclone center near the radar site. Wind speed and rainfall take maxima around the passage of the surface warm and cold fronts. Relatively short time scales of such wind and rainfall periods suggest that they are enhanced by some disturbances with scales smaller than the temperature and pressure change mainly due to the meso- $\alpha$-scale cyclone. In fact, we will demonstrate in subsequent sections the existence of meso- $\beta$ and $-\gamma$-scale cloud systems near the

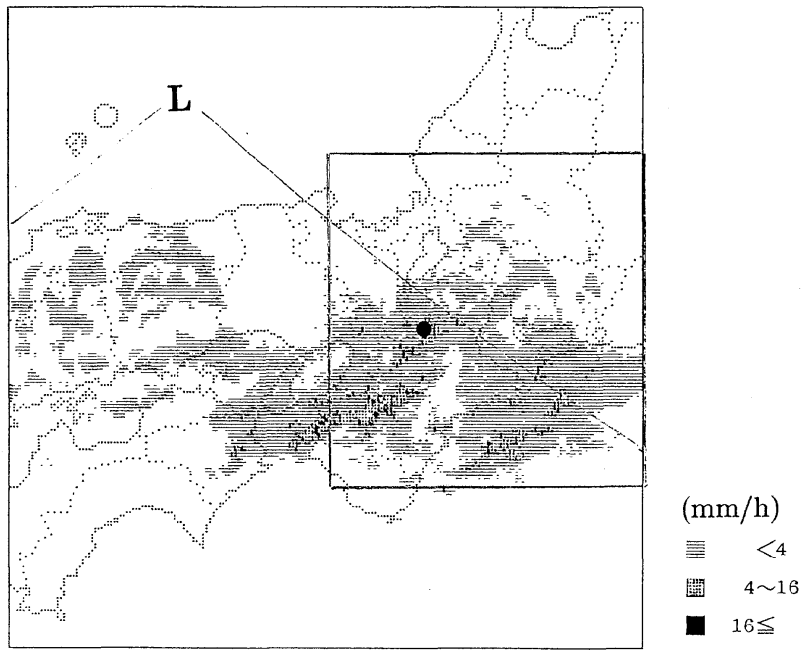

Fig. 5. Longitude-latitude cross-section of meso- $\alpha$-scale distribution of the precipitating cloud obtained by the C-band radar of OMO at 2100 LST 4 July. Black point is the MU observatory. Location of the cyclone center and the surface front is shown by a character of $\mathbf{L}$ and solid line, respectively. The region shown in square is magnified in Fig. 6.

surface warm and cold fronts (at around 2100 LST 4 and 0330 LST 5, respectively) and a stratiform cloud region on the north-western side of the surface cold front (between 0400-0600 LST 5). On the northern side of the surface warm front, several meso- $\beta$ and $-\gamma$-scale convective systems associated with strong updraft were found inside a stratiform cloud region, but these features are not described in this paper.

\section{Clouds near the surface warm front}

\subsection{Overall features of a meso- $\beta$-scale cloud system}

Figure 5 shows horizontal distribution of a meso$\alpha$-scale precipitating cloud at an altitude of $2 \mathrm{~km}$, which is obtained by Constant Altitude Plan Position Indicator (CAPPI) of the OMO C-band radar at 2100 LST 4 July. At the time, the surface warm front (solid line in Fig. 5) extending south-eastward from the cyclone center was located to the just eastern side of the radar site. Near the surface warm front, several precipitating clouds (4-16 mm/hour) in meso- $\beta$ and $-\gamma$ scale were dominant. From Fig. 6 , an echo (marked in the ellipse) almost passed on the southern side of the radar site between 20452100 LST, and the echo region almost disappeared at around 2145 LST. It moved almost eastward with a speed of about $18 \mathrm{~m} / \mathrm{s}$.

Here we investigate a relationship between the moving cloud system and a larger-scale flow (a background wind) associated with the meso- $\alpha$-scale cyclone. Figure 7 shows a mean horizontal wind obtained with the MU radar between 2000-2200 LST. The mean horizontal wind at an altitude of $2-3 \mathrm{~km}$ 

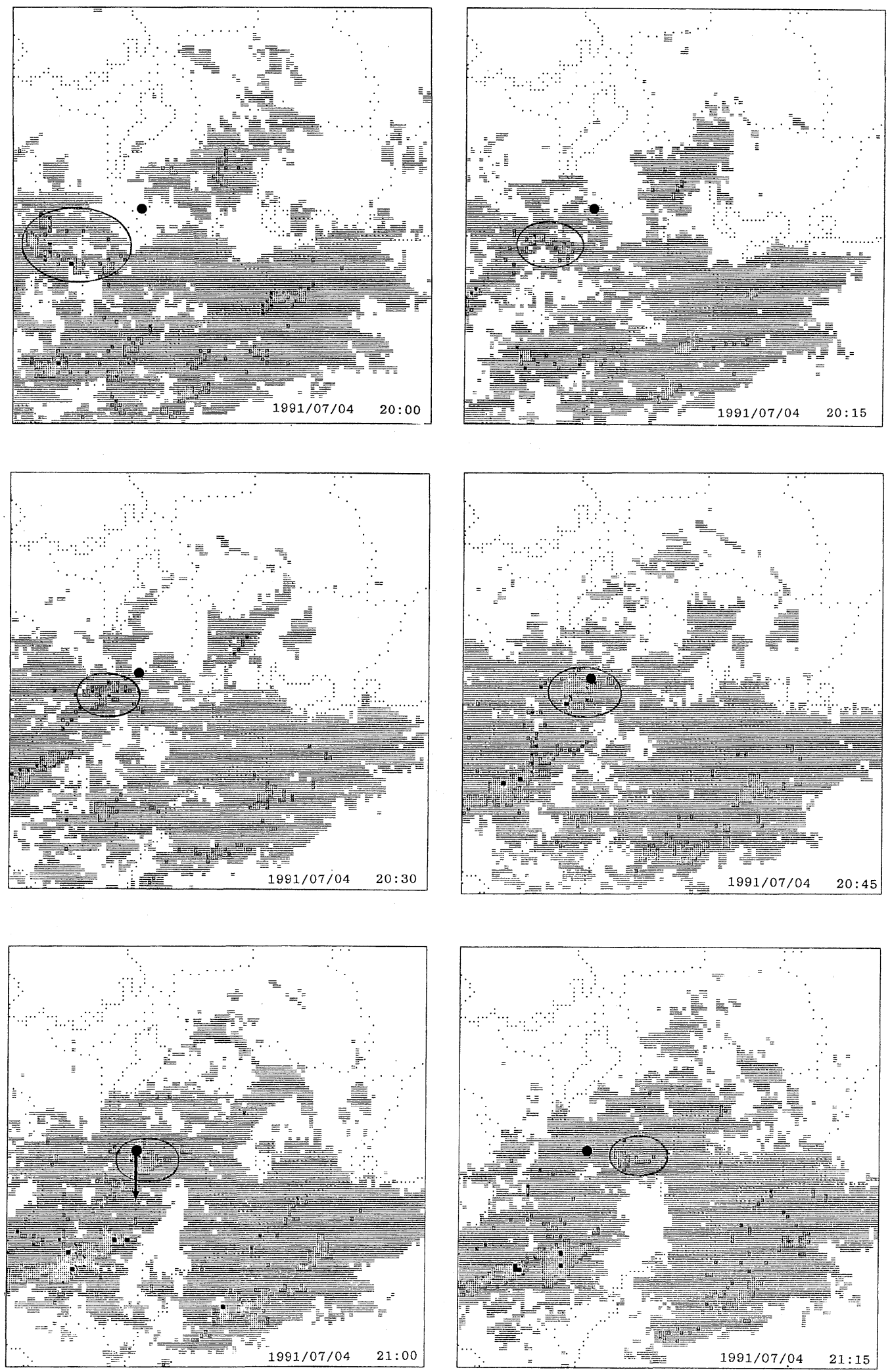

Fig. 6. Longitude-latitude cross-section of meso- $\beta$-scale distributions of the precipitating cloud obtained by the OMO C-band radar between 2000-2145 4 July at intervals of 15 min. Ellipse and black point are a target precipitating cloud and the MU observatory, respectively. Arrow indicates RHI direction shown in Fig. 10. 

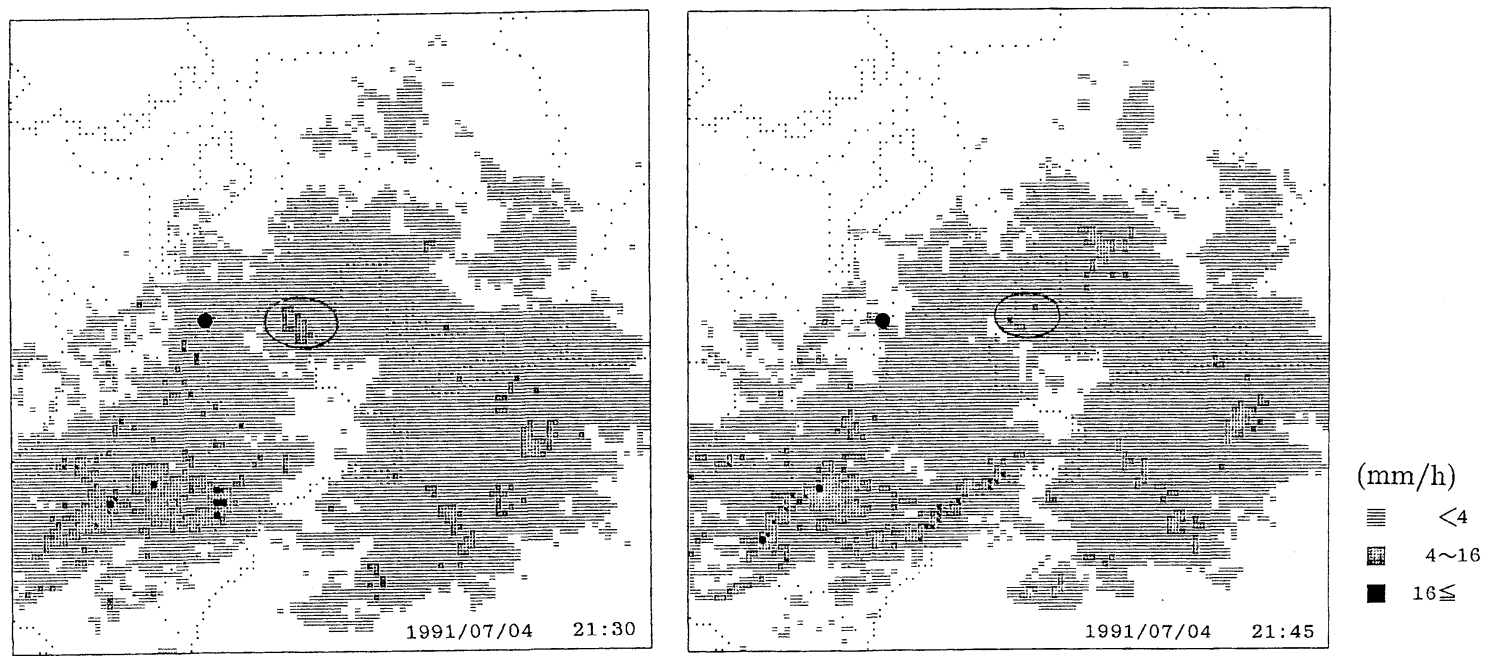

Fig. 6. (Continued)

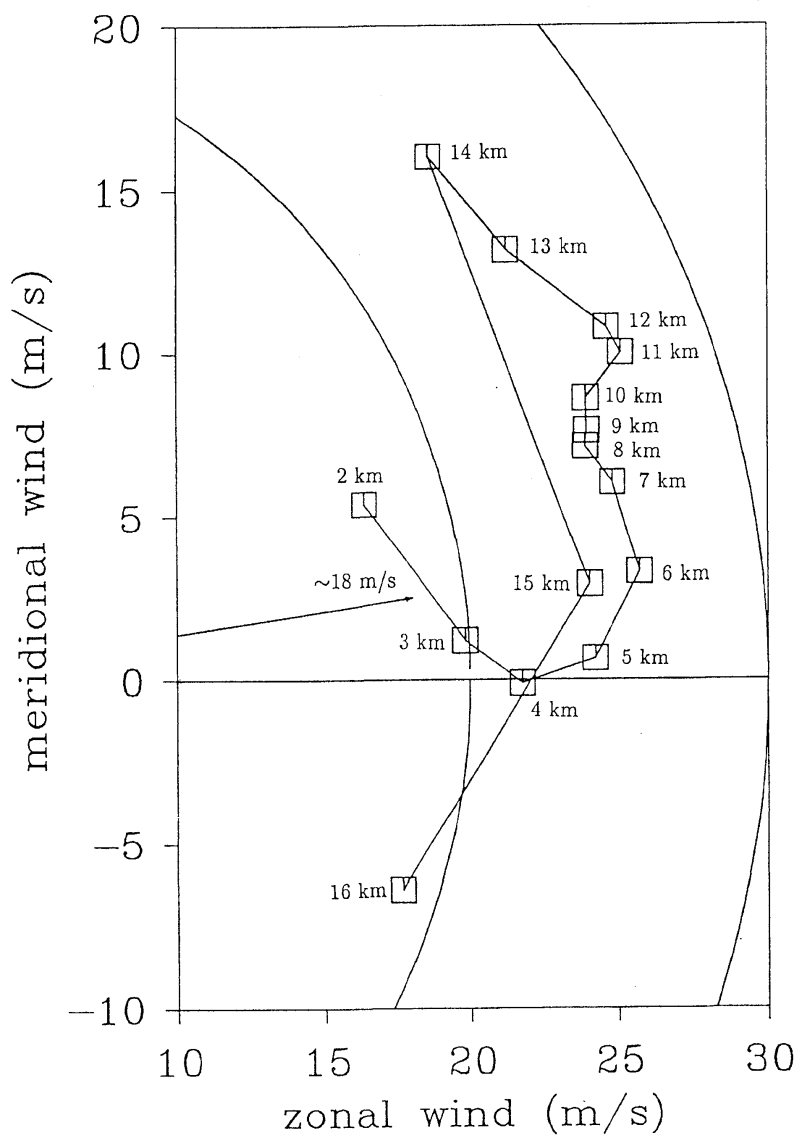

Fig. 7. Wind hodograph of the mean velocity observed by the MU radar between 2000-2200 LST 4 July. Vector shows the moving speed and direction of the cloud system (at an altitude of $2 \mathrm{~km}$ ) obtained from the OMO C-band radar.

was almost easterly with a speed of $16-19 \mathrm{~m} / \mathrm{s}$. It corresponded to the moving cloud system (shown by vector in Fig. 7) of the OMO meteorological radar data. However, the mean horizontal wind velocity remarkably increased with height; that is, the background wind velocity at the upper level was larger than that corresponding to the moving cloud system at the lower level. As the MU radar did not only observe the cloud system but also the surrounding environment, we consider that the cloud system moving away from the radar site is not sufficiently identified with the background wind there. Although the moving speed and direction of the cloud system at the lower altitude have been employed generally as the background wind in many studies for the mesoscale convective cloud with meteorological radar, we used the mean horizontal wind in Fig. 7 as the background wind and subtracted it from the observed horizontal wind at each altitude.

Figures $8 \mathrm{a}$ and $\mathrm{b}$ show THI (Time-Height Indicator) plots of zonal-vertical and zonal-meridional wind vectors between 2000-2200 LST, respectively. The horizontal wind is relative to the background wind. During this period, the vertical precipitation distribution could not be obtained by the RASC Cband radar due to system trouble, but could be detected by the precipitation echoes of the MU radar (which existed below solid lines in Figs. 8a and b). Surface rainfalls were also measured with a raingauge (see Fig. 8c). Contours in Figs. 8a and b show echo intensity obtained by the MU radar. The contribution of precipitation echoes have been removed based on a method described in Shibagaki et al. (1997). Since the Doppler spectra of a VHF (Braggscatter) radar in the cloud are enhanced and broadened by shear between a strong upward motion and environment, by variance of thermodynamical quantities due to condensation and evaporation, and by a negative covariance between temperature and humidity due to supersatuation (see, e.g., Fukao et al. 1985a; Gossard 1979; Wakasugi et al. 1987), we may roughly regard a vertically extending strong echo 


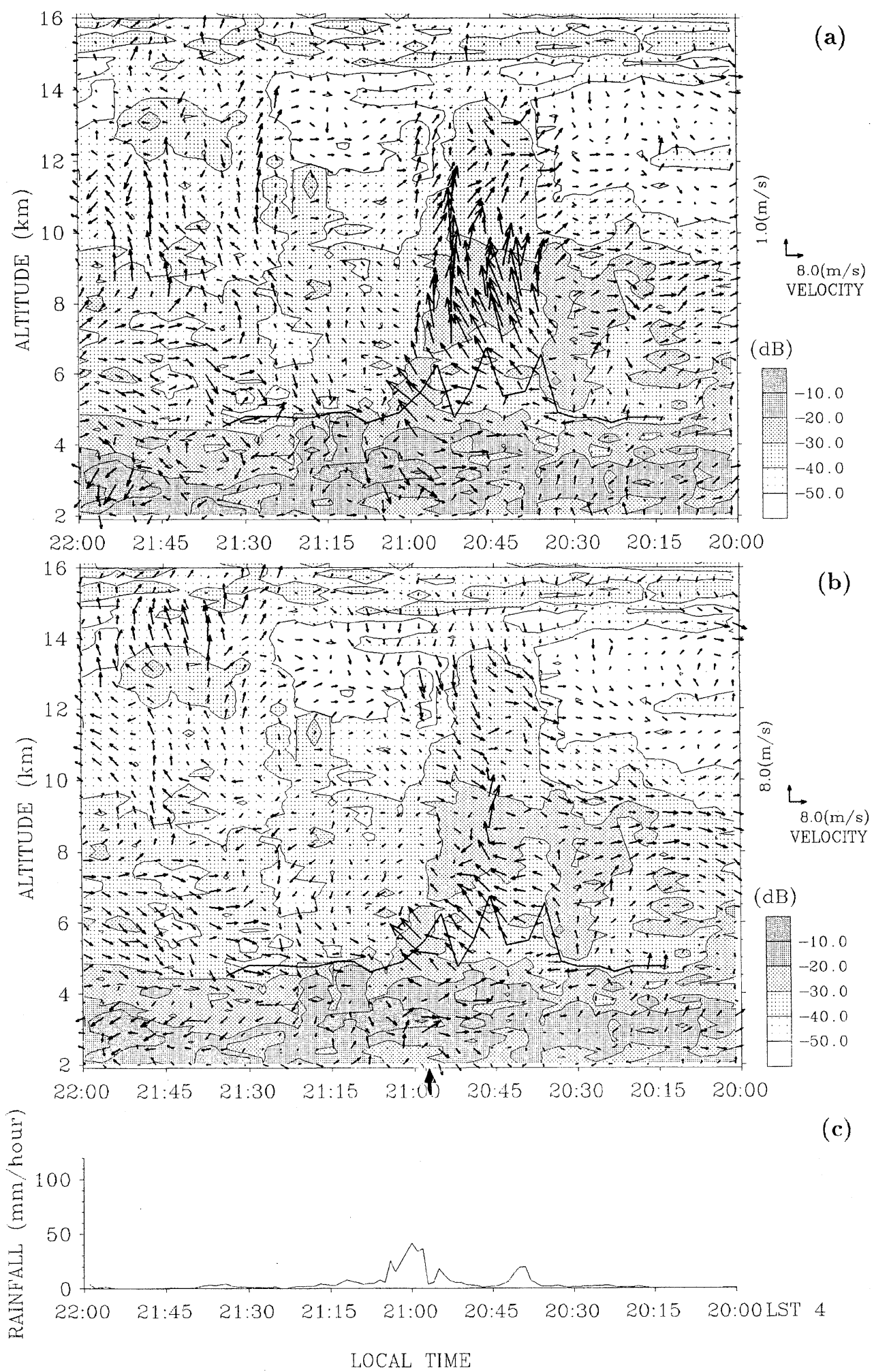

Fig. 8. THI plots of (a) zonal-vertical and (b) zonal-meridional winds (vectors) observed by the MU radar, and (c) rainfall on the ground between 2000-2200 LST 4 July. Contour is the vertical echo intensity associated with the vertical distribution of the precipitating cloud. Since the MU data has some missing data, they are linearly interpolated if the missing data does not continue over $9 \mathrm{~min}$ in time series and $1 \mathrm{~km}$ in height series. The MU data is indicated by 3 -min and $450-\mathrm{m}$ intervals in time and height, respectively. The mean velocity (in Fig. 7) during this period is subtracted from the observed horizontal wind. Solid line is the top level of the precipitation echoes observed by the MU radar. Arrow in the bottom of (b) is at the time of RHI shown in Fig. 10. 
region as the "cloud" region. As the cloud system moved almost eastward in this case, we may approximately regard the strong echo region as the zonalvertical cross-section of the cloud system. We found two precipitating clouds associated with updraft regions in the middle troposphere between 2030-2100 and 2120-2155 LST. The former was identified with the strong reflectivity echo region in Fig. 6, while the latter was observed as the weak reflectivity echo region in the same figure. The vertical velocity of the former was stronger than that of the latter. In the next subsection, we shall describe meso- $\gamma$-scale features mainly about the former developing cloud.

\subsection{Meso- $\gamma$-scale air motion associated with the de- veloping cloud}

The precipitating cloud observed between 2030 2100 LST had typical convection-like features in the middle troposphere. The mean cloud top near the radar site was roughly obtained by the OMO C-band radar at around $2100 \mathrm{LST}$, and it was at an altitude of about $10 \mathrm{~km}$ (not shown here). We can find that it is coincident with the mean top level of the region of $-40 \mathrm{~dB}$ value in the vertical echo intensity of the MU radar. From this fact we assumed that the developing cloud top (corresponding to contour line of $-40 \mathrm{~dB}$ value) was extending up to an altitude of about $14 \mathrm{~km}$. An easterly wind was entering into the cloud from the forward region at an altitude of $4-$ $5 \mathrm{~km}$, and it turned upward inside the precipitating cloud. The upward flow was remarkably strong in an altitude range between $5.0-11.5 \mathrm{~km}$. In the upper troposphere, the zonal wind became gradually westerly inside the precipitating cloud, and the flow went out ahead of it. Around the estimated cloud top, weak downdraft was also observed and seemed to converge with the westerly outflow. The meridional wind was southerly in the middle troposphere and changed to northerly in the upper altitude inside the precipitating cloud.

In the rear of the convective portion, vertical velocity became very weak above an altitude of $5 \mathrm{~km}$. Downdraft was observed in the lower troposphere (below the altitude of $5 \mathrm{~km}$ ), which was associated with rainfall on the ground ( $45 \mathrm{~mm} /$ hour at maximum, as shown in Fig. 8c). The westerly wind coming from the rear region was seen in this region.

In Fig. 9 we have analyzed potential temperature $(\theta)$, equivalent potential temperature $\left(\theta_{e}\right)$ and saturated equivalent potential temperature $\left(\theta_{e}^{*}\right)$, based on the data of a radiosonde launched from the MU radar site at $2025 \mathrm{LST}$ (before the passage of the developing cloud). Air was saturated, and stratification was almost neutral, except for a stable layer near an altitude of $5 \mathrm{~km}$. Between 2015-2035 LST, the top of the vertical distribution of precipitation echoes observed by the MU radar (solid line shown in Figs. 8a and b) corresponded well to the melt-

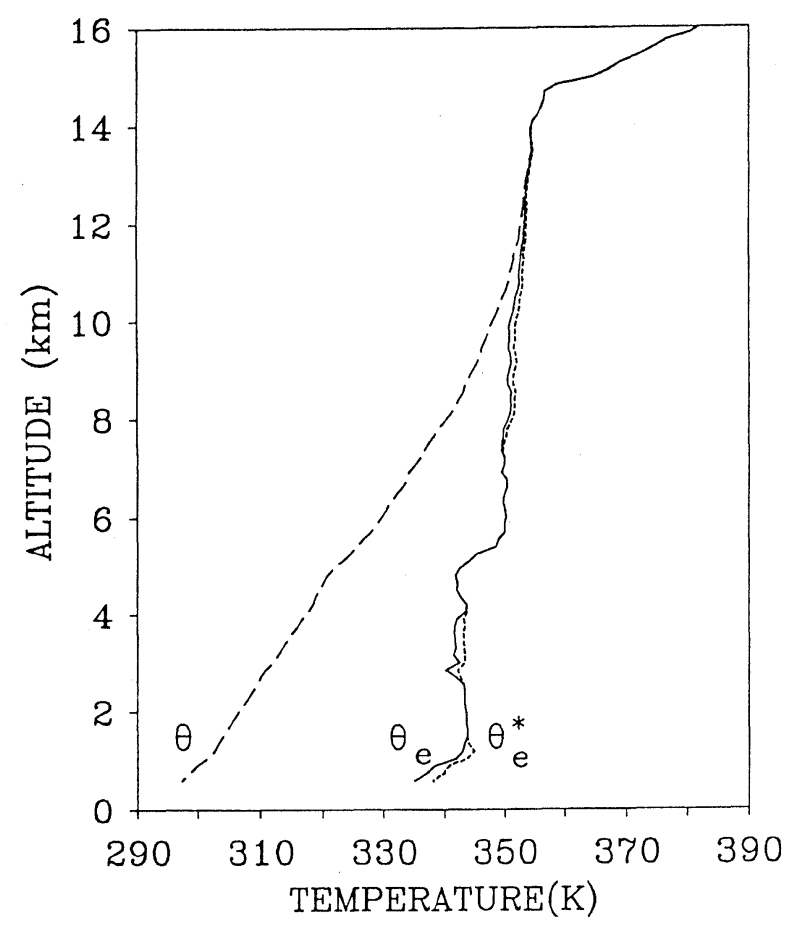

Fig. 9. Vertical profiles of potential temperature $(\theta)$ (solid curve), equivalent potential temperature $\left(\theta_{e}\right)$ (dashed curve) and saturated $\theta_{e}\left(\theta_{e}{ }^{*}\right)$ (dotted-dashed curve) calculated from radiosonde data of the radar site at 2025 LST 4 July (before the passage of the developing cloud).

ing layer (with temperature $\sim 0^{\circ} \mathrm{C}$ ) from the radiosonde, which was located at an altitude of about $4.8 \mathrm{~km}$. In the passage of the developing cloud between 2035-2100 LST, the level ascended up to an altitude of about $6.5 \mathrm{~km}$ and three times rapidly descended to an altitude of about $5 \mathrm{~km}$. The rapid change of these echoes is considered to be associated with the descent of solid precipitation particles grown in strong updrafts.

\subsection{Southward structure of the developing cloud}

Figure 10 shows an Range Height Indicator (RHI) plot of radial velocity obtained by the X-band radar for $181^{\circ}$ azimuth angle at $2057 \mathrm{LST}$, and a vertical profile of radial velocity for the same azimuth angle observed simultaneously with the MU radar. Positive and negative values correspond approximately to southerly and northerly winds relative to the background wind. The RHI plane passed through the center of the developing cloud, as indicated by an arrow in Fig. 6. Over the MU radar, strong southerly wind appeared at altitudes of 2.0-3.0 and $4.0-6.5 \mathrm{~km}$, and very weak northerly wind was observed at an altitude of 3.5 and above an altitude of $6.5 \mathrm{~km}$. The X-band radar data indicate that the southerly wind was dominant in an altitude range of $2.0-6.0 \mathrm{~km}$ over the entire precipitating cloud region, and that northerly wind was dominant both 


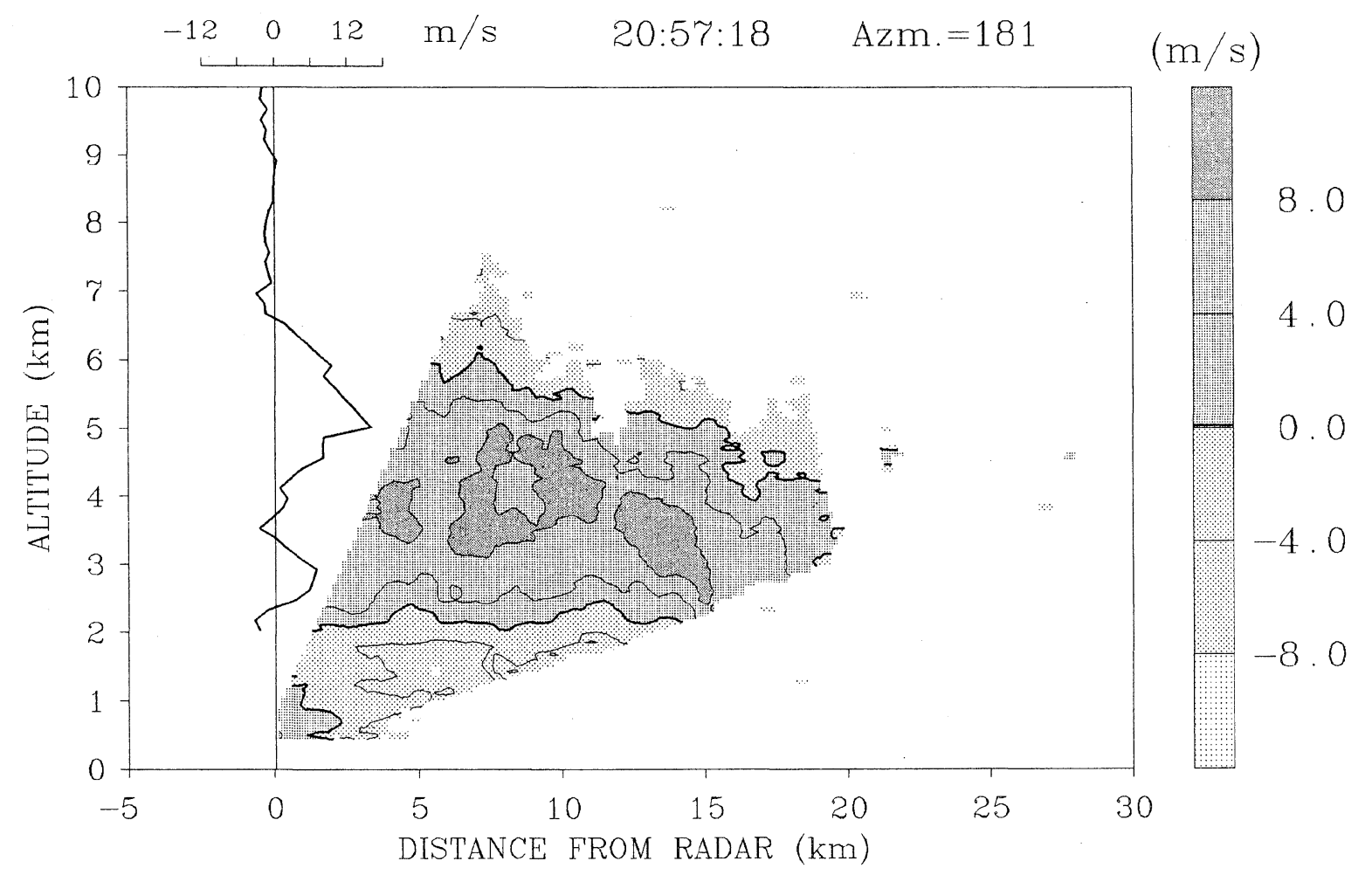

Fig. 10. RHI plot (contour) of radial velocity observed by the X-band radar in the azimuth angle of $181^{\circ}$ at 2057 LST 4 July. The RHI direction is shown by the arrow in Fig. 6 . The profile is radial velocity obtained by the MU radar for the same azimuth angle. The background wind in Fig. 7 is subtracted from the observed radial velocity. The background wind below an altitude of $2 \mathrm{~km}$ that the MU radar cannot observe, was employed by the lowest altitude (the altitude of $2 \mathrm{~km}$ ) of the MU radar data.

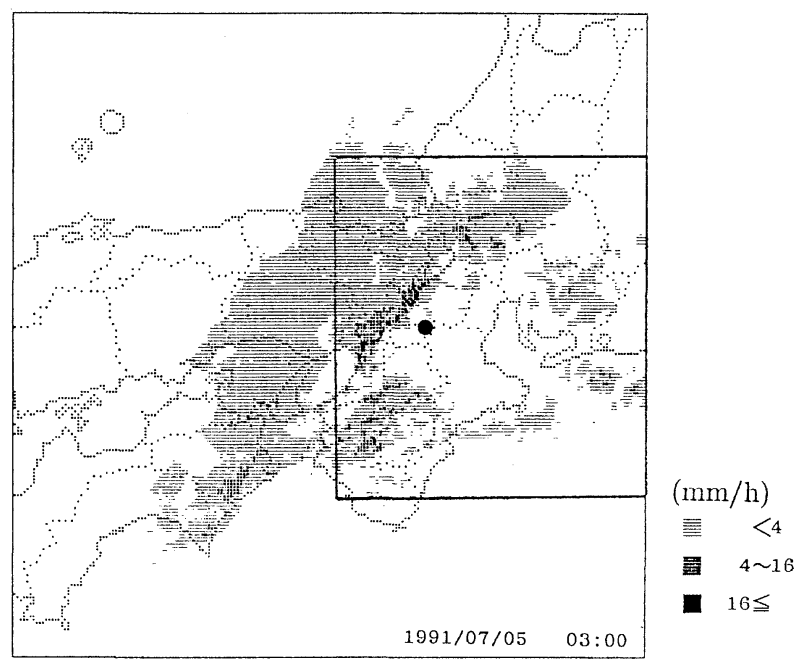

Fig. 11. Same as Fig. 5, but at 0300 LST 5 July. The region shown in square is magnified in Fig. 12.

above and below this altitude zone. From this result, we suppose that the inflow of intense southerly wind with high humidity is important for development of the precipitating cloud.

\section{Clouds near the surface cold front}

\subsection{Motions associated with narrow rainbands}

Figure 11 shows a horizontal distribution of precipitating clouds observed by the OMO C-band radar at 0300 LST 5 July. A meso- $\beta$-scale cloud cluster extending from southwest to northeast moved east-northeastward at a speed of about $22 \mathrm{~m} / \mathrm{s}$. It was associated with a surface cold front. A strong echo region (rainband $\mathrm{B}$ ) at the leading edge of the cloud system was seen in Fig. 12. Between 03000330 LST, the band-like system seemed to move south-eastward and approached the radar site because an echo in the northern region of the rainband became weak and an echo was developed in the southern region. It began to separate into two regions at around $0307 \mathrm{LST}$, and two arc-shape rainbands were clearly seen after 0330 LST. In this paper the earlier (east) and later (west) rainfall regions are defined as rainbands B1 and B2, respectively, which correspond to rainbands $\mathrm{A}$ and $\mathrm{B}$, respectively in another study by Takahashi et al. (1995). 

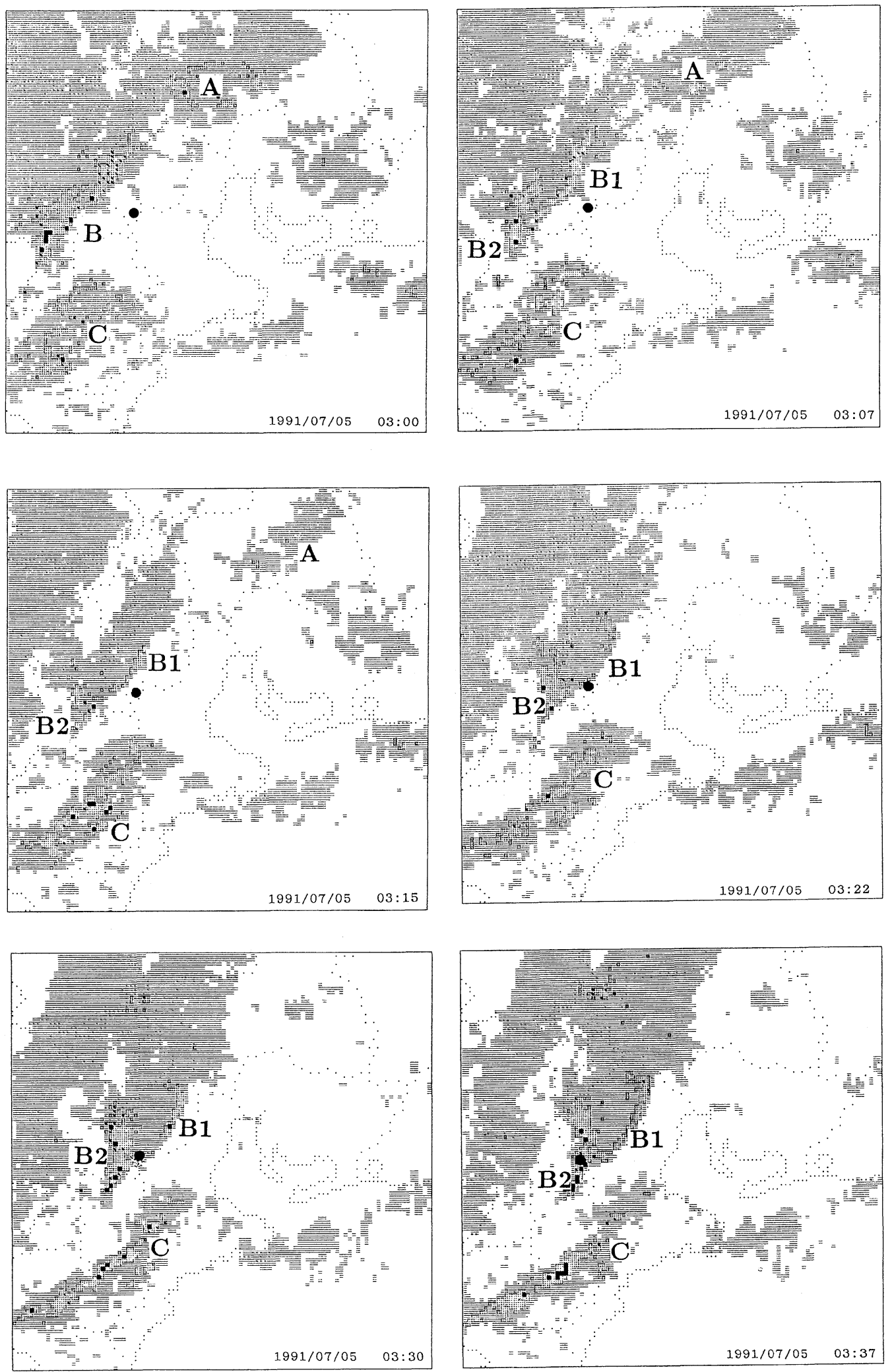

Fig. 12. Same as Fig. 6, but between 0300-0352 LST 5 July. The data intervals are about 8 min.

Figures 13a and b show THI plots of zonal-vertical and zonal-meridional winds (vectors), respectively, observed by the MU radar between 0300-0400 LST. Figure 13c shows the surface rainfall, which was clearly separated into two periods corresponding to the rainbands B1 and B2 mentioned above. Here the mean horizontal wind (shown in Fig. 14) had a southerly component in the lower troposphere that 

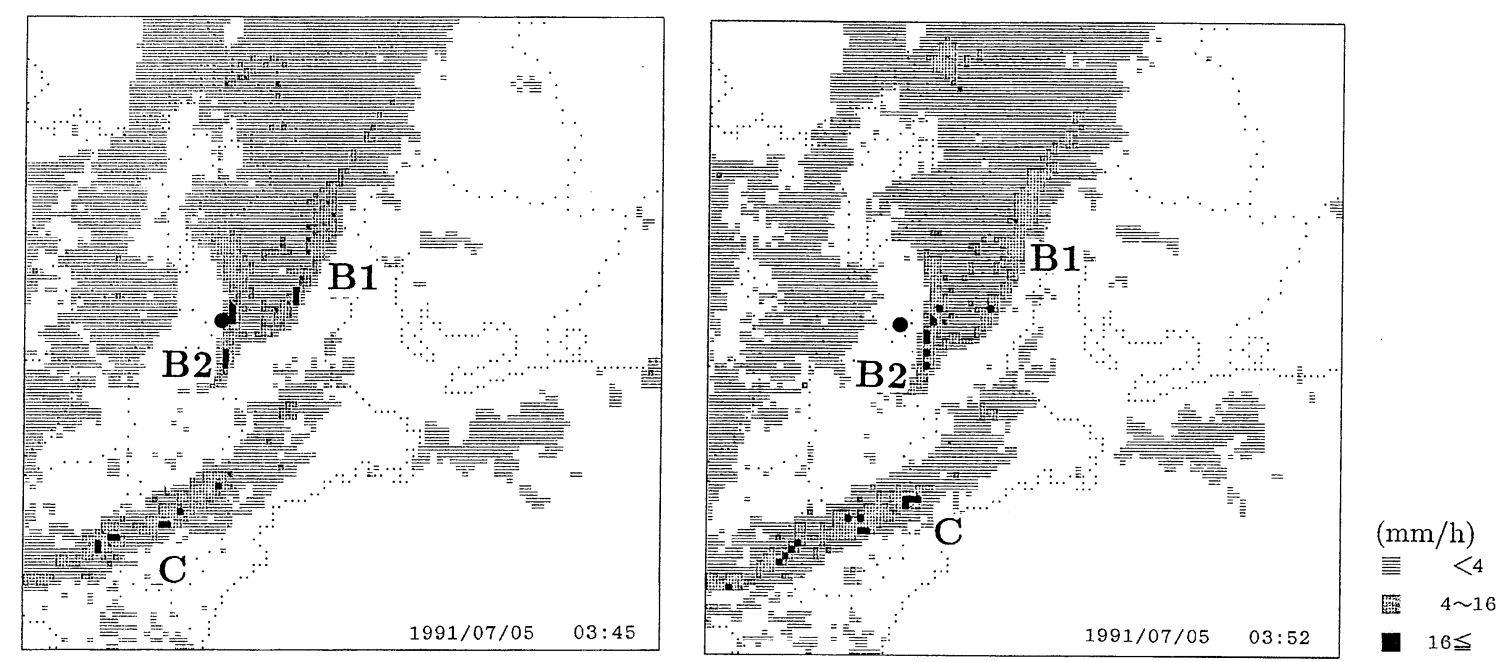

Fig. 12. (Continued)

differed from the moving direction of the rainband B1. It is recognized that the background wind almost corresponded to the moving cloud system in meso- $\beta$ scale, as shown by vector in Fig. 14 . The wind component in Fig. 14 is subtracted from the observed horizontal wind. In vertical precipitation distribution obtained by the RASC C-band radar (shown by contours in Fig. 13), a strong reflectivity echo region reaching an altitude of 4.0-5.5 km was observed between 0322-0335 LST, and it was identified with the rainband B1. Just before the passage of the rainband, meridional wind below an altitude of about $3 \mathrm{~km}$ changed from southerly to northerly at 0320 LST. The feature is also confirmed from the wind data on the surface in Figs. $4 \mathrm{c}$ and d. The detailed features of the rainband B1 with the horizontal shear will be described in Subsection 5.2.

As shown in Fig. 13, the echo top of the rainband B2 was extended up to an altitude of about $12 \mathrm{~km}$, and strong updraft occurred in an altitude range of 6-10 km between 0336-0345 LST. However, we cannot study detailed wind behavior inside the precipitating cloud, because some data were missing due to irregular echoes of the MU radar during this period. Furthermore, we confirmed that distinct precipitation echo of the MU radar inside the rainband $\mathrm{B} 1$ and B2 existed below altitudes of about $3.5 \mathrm{~km}$ and $5.0 \mathrm{~km}$, respectively (not indicated here).

\subsection{Structure of rainband B1}

Figures $15 \mathrm{a}$ and $\mathrm{b}$ show RHI plots of radial velocity and reflectivity (contours), respectively, observed with the X-band radar at an azimuth angle of $345^{\circ}$ at 0311 LST. The movement of the rainband $\mathrm{B} 1$ to the radar site is demonstrated by two successive echoes in PPI at an elevation angle of $4^{\circ}$ as shown in Fig. 16. A long arrow indicates the RHI direction. Although the cloud movement direction (south-eastward) is different from the RHI direction, the figure can be regarded as the vertical cross-section of the rainband B1 under an assumption that it has the same flow-pattern inside the entire region of the band-like system. The radial velocity (horizontal wind component in the azimuth angle of $345^{\circ}$ ) and radial-vertical wind observed by the MU radar are plotted by vertical profiles in Fig. 15a and by vectors in Fig. 15b, respectively, under an assumption that the wind system moved with the speed of the rainband. The MU radar data plotted here was obtained between 0312-0332 LST while the rainband B1 approached and passed near the radar site. Positive and negative values are approximately north-northwesterly and south-southeasterly winds, respectively, relative to the background wind.

In Fig. 15a, a convergence of south-southeasterly and north-northwesterly winds can be clearly seen below an altitude of about $3 \mathrm{~km}$ with a distance of $12-13 \mathrm{~km}$ from the radar site. We found a gust front with the intense convergent flow below an altitude of $2 \mathrm{~km}$ (as indicated by a solid line). The depth of the gust front from surface was about $1.6 \mathrm{~km}$. A divergent flow was seen in an altitude of $3-6 \mathrm{~km}$ above the convergent flow. The MU radar data was almost coincident with the X-band radar data in spite of a maximum time difference between them of about $20 \mathrm{~min}$, except for a small vertical shift $(\sim 1 \mathrm{~km})$ between those two data at an altitude of about $3 \mathrm{~km}$ with a distance of $17-20 \mathrm{~km}$ from the radar site. The vertical shift may be produced by the downward velocity component of raindrops observed by the X-band radar. Further the X-band radar data showed more complicated features than the $\mathrm{MU}$ radar data around the rainband and also in the region below an altitude of about $2 \mathrm{~km}$, which cannot be observed by the MU radar.

In Fig. 15b a strong echo of the X-band radar data was located in an altitude of $0.5-6.5 \mathrm{~km}$ with 

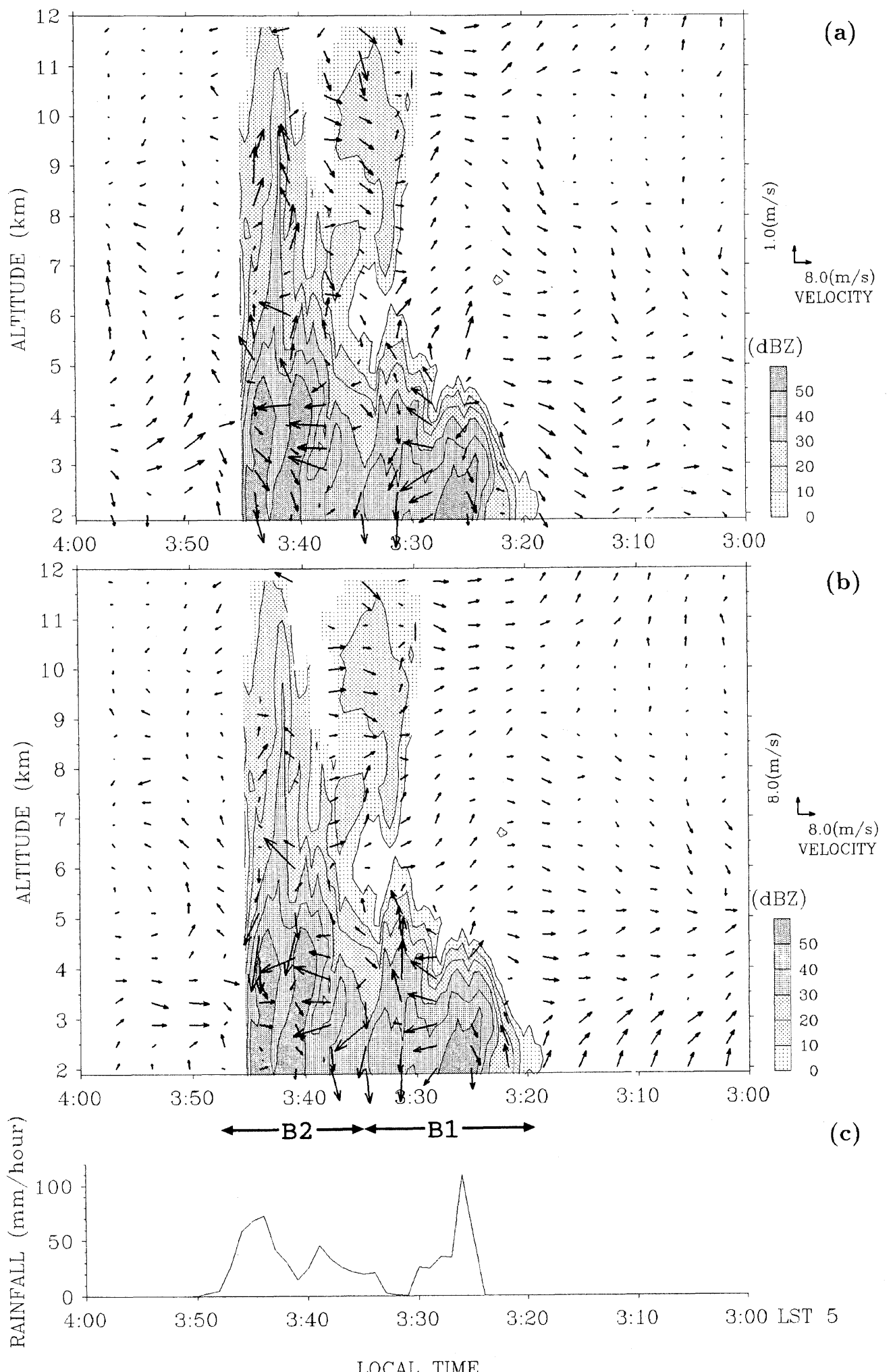

Fig. 13. THI plots of (a) zonal-vertical and (b) zonal-meridional winds (vectors) observed by the MU radar, and (c) rainfall on the ground between 0300-0400 LST 5 July. Here the MU data is not linearly interpolated for time series, because in the precipitating echo too much data is missing. The mean velocity (in Fig. 14) during this period is subtracted from the observed horizontal wind. Contour is the vertical distribution of the reflectivity obtained by the RASC C-band radar. The data intervals in time and height are $30 \mathrm{sec}$ and $300 \mathrm{~m}$, respectively. There is missing data between 0346-0354 LST 5 July. 


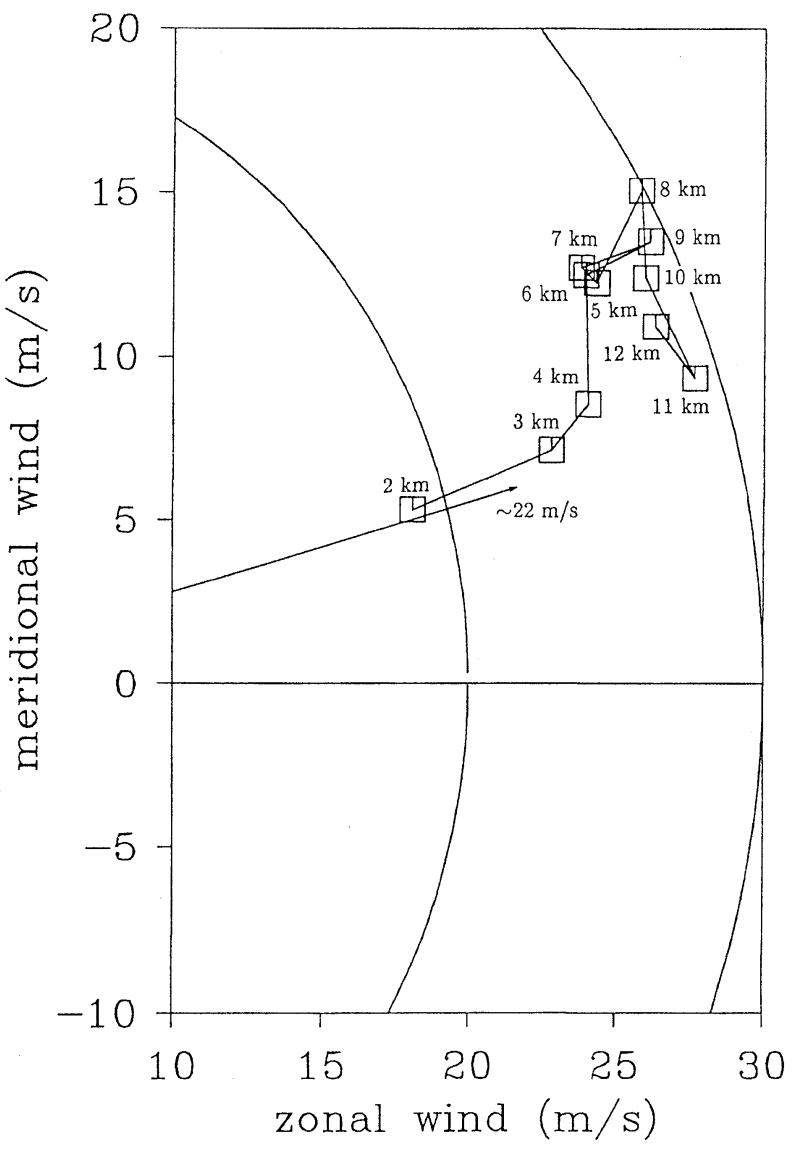

Fig. 14. Same as Fig. 7, but between 0300-0400 LST 5 July.

a distance of $13-21 \mathrm{~km}$ from the radar site. The shape of the rainband was similar to that of the reflectivity echo of the rainband B1 shown in Fig. 13, except for the region below an altitude of about $4 \mathrm{~km}$ with a distance of 18-21 from the radar site, where a reflectivity echo did not exist. The flow patterns obtained from the $\mathrm{MU}$ and $\mathrm{X}$-band radar data in Fig. 15a also had almost the same structure. These facts support the assumption mentioned above for horizontal and temporal variations of the rainband. South-southeasterly wind coming from the front of the rainband was ascending along the strong reflectivity echo. A portion of the upward flow seems also to be returned to the front region in an altitude of $3-5 \mathrm{~km}$, and the flow descended in a distance of 4-8 km from the radar site. As a result, a meso- $\gamma-$ scale circulation (shown in the rectangle) was composed of these flows in front of the rainband, and it was found in the region without precipitation which the meteorological radar cannot observe. Inside the rainband, a remarkable downdraft associated with strong rainfall intensity on the ground (maximum $110 \mathrm{~mm}$ /hour in Fig. 13c) occurred. The gust structure at the leading edge of the rainband seems to be reinforced by the north-northwesterly wind associated with the downdraft.
6. Clouds of the north-western side of the surface cold front

After the two rainbands described in Section 5 passed over the radar site, we observed wind distribution inside a stratiform cloud system on the north-western side of the surface cold front. Figure 17 shows a horizontal distribution of precipitating clouds obtained by the OMO C-band radar between 0400-0530 LST 5 July. In this period, there was only weak rainfall $(<4 \mathrm{~mm} / \mathrm{h})$.

Figures $18 \mathrm{a}$ and $\mathrm{b}$ show THI plots of zonal-vertical and zonal-meridional winds relative to a background wind (in Fig. 19 shown later), respectively, observed by the MU radar between 0400-0600 LST. Contours indicate a vertical distribution of reflectivity observed by the RASC C-band radar. The moving speed (around $20 \mathrm{~m} / \mathrm{s}$ ) and direction (almost eastward) of the rainband far away from the radar site is relatively corresponding to the mean horizontal wind at the lower troposphere in Fig. 19. The region of reflectivity echoes more than $20 \mathrm{dBZ}$ was gradually ascending from an altitude of about $5 \mathrm{~km}$ at $0450 \mathrm{LST}$ up to an altitude of about $9 \mathrm{~km}$ at 0520 LST. A reversal level of horizontal wind direction appeared clearly along the strong reflectivity region. This structure is quite similar to that observed near the cold frontal surface with meteorological Doppler radar and radiosondes by Browning and Harrold (1970). Thus, it is inferred that the reversal level of horizontal wind may correspond to the upper boundary of the cold frontal surface, although temperature and humidity data at the radar site was not available during this period.

Easterly (or south-easterly) wind was dominantly observed just above the sloping cold frontal surface, which was accompanied by weak reflectivity echoes ( $<20 \mathrm{dBZ}$ ). Remarkable descending north-westerly wind was observed inside/under the cold frontal surface. These behaviors of the horizontal wind component above and inside/under the cold frontal surface were accompanied by upward and downward motions, respectively. Weak westerly wind below the cold frontal surface changed again to easterly in an altitude range of $3-5 \mathrm{~km}$ after $0505 \mathrm{LST}$, and the region is dry without precipitation.

Between 0400-0450 LST, the reversal level of the zonal wind corresponding to the upper boundary of the cold frontal surface was located at an almost constant altitude of about $5 \mathrm{~km}$. The region of upward velocity appeared inside the precipitating cloud. In the shear layer between the upper-level westerly and the middle-level easterly flows near the beginning of ascent of the frontal surface (in an altitude of 7$10 \mathrm{~km}$ between 0425-0450 LST), rotor circulation (vertical scale $\sim 3 \mathrm{~km}$ and horizontal scale $\sim 22 \mathrm{~m} / \mathrm{s}$ $x \sim 1400 \mathrm{~s} \sim 28 \mathrm{~km}$ ) was observed. 


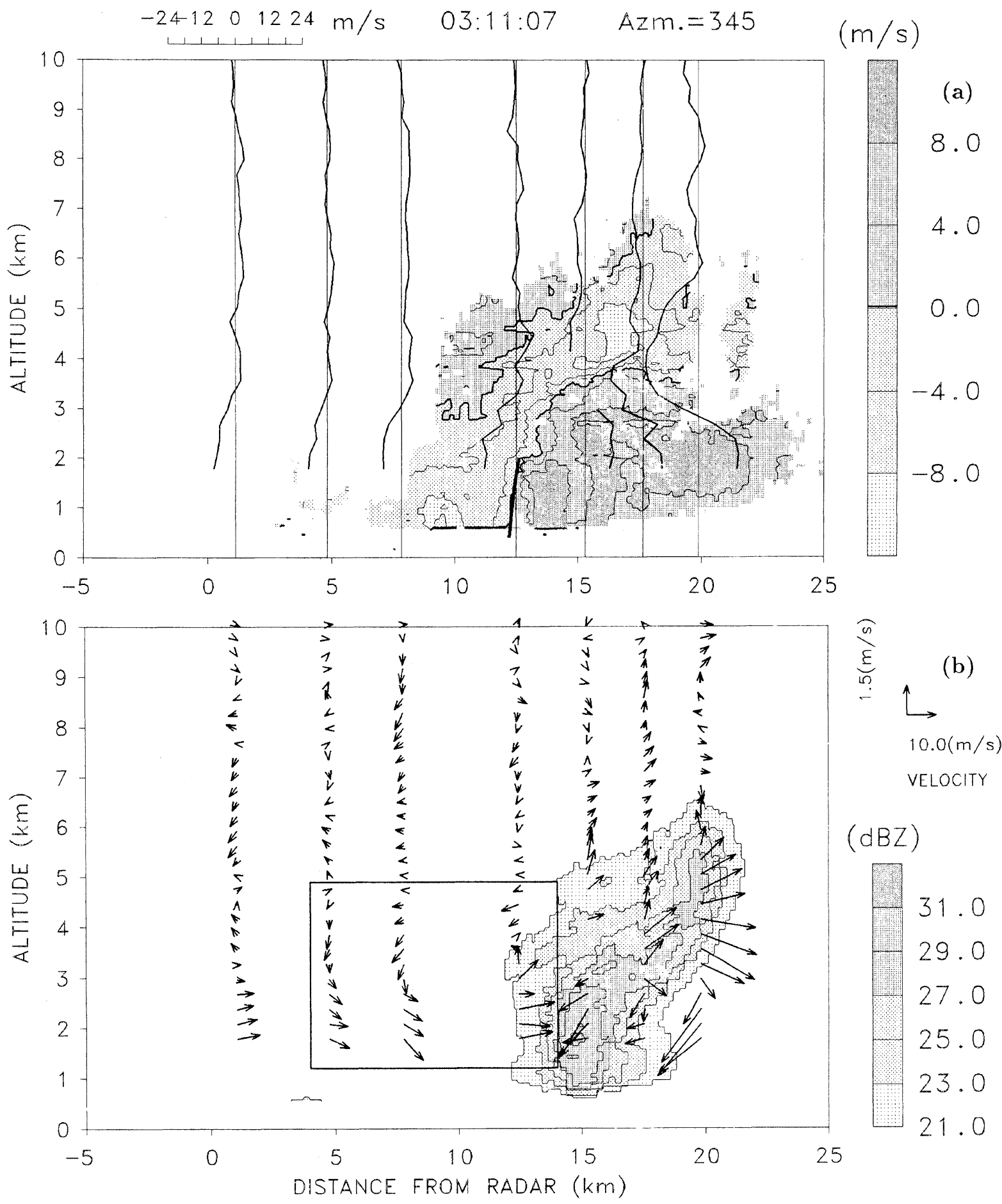

Fig. 15. RHI plots (contour) of (a) radial velocity and (b) reflectivity observed by the X-band radar for the azimuth angle of $345^{\circ}$ at 0311 LST 5 July. Profiles and vectors indicate the radial velocity and radial-vertical wind obtained by the MU radar for the same azimuth angle, respectively. The MU radar data employs between 0312-0332 LST 5 July, and each distance of the profiles shows a position of the radar site relative to the moving rainband. Positive and negative values are approximately north-northwesterly and south-southeasterly winds relative to the background wind. In (a) solid line indicates the gust front. For a rectangle in (b), see text. 


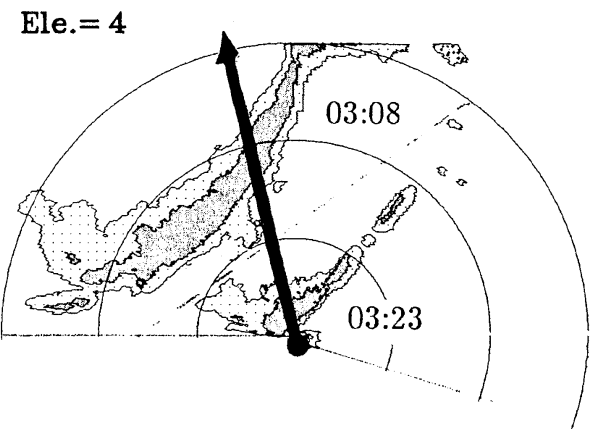

No data

$(\mathrm{dBZ})$

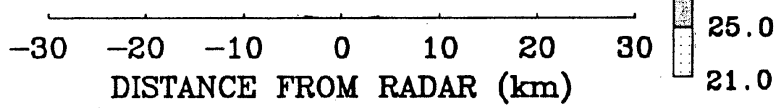

Fig. 16. PPI plot of the rainband B1 observed by the X-band radar for elevation angle of $4^{\circ}$ at 0308 and 0323 LST 5 July. Black point and arrow indicate a position of radar site and RHI direction shown in Fig. 15, respectively. The missing area of PPI data is due to a mountain located on the southern side of the radar site.

\section{Wind circulations associated with precip- itating clouds}

Figure 20 shows a schematic illustration of a hierarchical structure from meso- $\alpha$ to $-\gamma$-scale cloud system associated with the meso- $\alpha$-scale cyclone. Panel (a) shows the asymmetric distribution of cloud clusters near the cyclone center, which have been reported frequently as the meso- $\alpha$-scale cloud system along the Baiu front in the west region of the Japan Islands, such as in a schematic model of multiscale structure presented by Ninomiya and Akiyama (1992). In this study these were observed in further detail by the MU and RASC C-band radars. The vertical distributions of vertical velocity and precipitation particles associated with the meso- $\alpha$ scale cloud system (a) are shown in (b). From the OMO C-band radar, convective clouds near the surface warm front are characterized by several meso$\beta$ and $-\gamma$-scale clouds inside the meso- $\alpha$-scale cloud cluster, while those near the surface cold front have band-like structure along the surface cold front. The behaviors of the vertical motion have features as follows; intermittent upward motions in meso- $\gamma$ scale appear inside the developing cloud on the northern side of the surface warm front and meso- $\beta$-scale upward motions without precipitation on the northern side of surface cold front. They have been partly described in Shibagaki et al. (1997). In this paper, wind circulations (relative to the cyclonic flow around the meso- $\alpha$-scale cyclone) associated with the meso- $\beta$ and $-\gamma$-scale cloud systems are described below for the three regions defined as (c1) near the surface warm front, (c2) near the surface cold front, and (c3) on the the north-western side of the surface cold front.

\subsection{The region near the surface warm front}

The meso- $\gamma$-scale wind circulations near the surface warm front are shown in the panel (c1) of Fig. 20. The remarkable updraft region in the altitude range between $5.0-11.5 \mathrm{~km}$ is caused by the convergence of inflows coming from the front and rear regions at the altitude of $4-5 \mathrm{~km}$. The level of the convergent flow is higher than that of the gust front structure inside a convection cell of a squall line in the midlatitude (e.g., Smull and Houze 1985, 1987a, b; Houze et al. 1989) and inside a warm sector rainband near the extratropical cyclone (e.g., Hobbs et al. 1980). Thus, the developing cloud is the convective cloud in the middle troposphere and distinguished from a deep convective cloud with the gust front. In the upper troposphere the ascending flow leads to the outflow in front of the developing cloud, and it appears to be combined with the downdraft (associated with northerly wind) extending from the estimated cloud top level. The top level of the precipitation echoes observed by the MU radar changes three times inside the convective region. The characteristics may represent the descent of solid precipitation particles grown in the strong updrafts, and the descending particles may cause rainfall behind the convective region. Further, the developing cloud has the strong southerly wind in the middle troposphere, and the intense southward inflow is also observed in the south part of the developing cloud from the RHI plane of the X-band radar. This fact may suggest that the strong southward inflow with high humidity inside the meso- $\beta$-scale cloud is an important factor for the development of cumulonimbus cloud.

\subsection{The region near the narrow cold front}

The narrow rainband (rainband B1 defined in Section 5.1) is shown in the panel (c2) of Fig. 20. At the leading edge of the rainband the intense convergence of these south-southeasterly and northnorthwesterly winds below the altitude of $2 \mathrm{~km}$ is identified with the gust front. The inflow coming from the front of the rainband ascends along the echo top of the rainband. Outflow ahead of the rainband appears above the inflow coming to the rainband at the lower levels. Furthermore, the flow descends with the distance of 6-9 km from the rainband. As a result, meso- $\gamma$-scale rotor circulation is found in the region without precipitation in front of the rainband. The flow pattern resembling the rotor circulation, which is organized by upward motion toward the rear region of the gust front and downward motion from the rear region to the gust front, is also observed inside the rainband with heavy rainfall. 

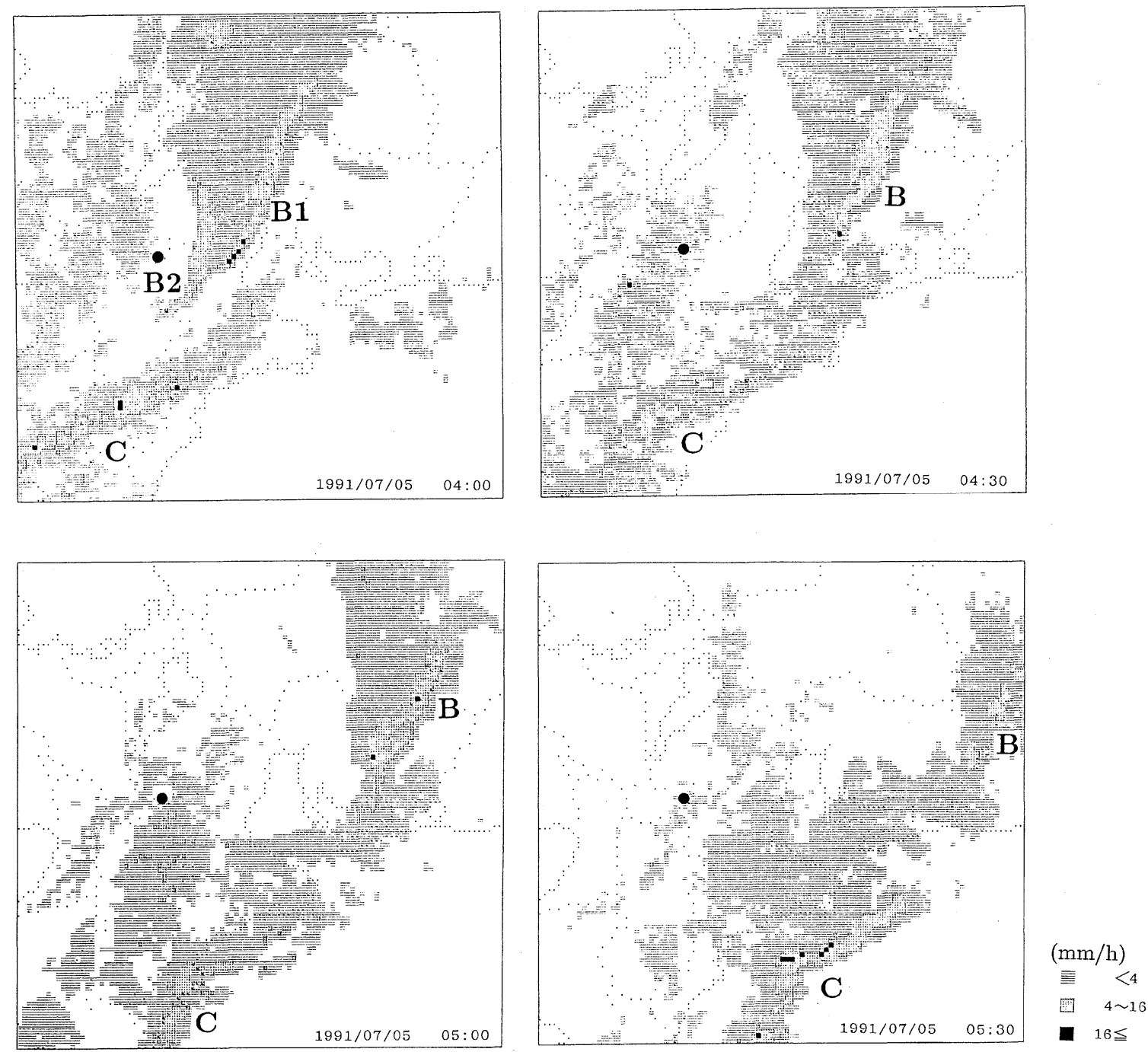

Fig. 17. Same as Fig. 6, but between 0400-0530 LST 5 July.

From the surface meteorological data in Fig. 4, a pressure rise of $1.7 \mathrm{hPa}$ (meso high) was found just before the rainband $\mathrm{B} 1$ passed over the radar site. A temperature fall of $1.4^{\circ} \mathrm{C}$ (cold pool) was also observed during the passages of the rainband $\mathrm{B} 1$ and B2. The cold pool may be generated by cooling due to evaporation of precipitation particles. The meso high is considered to be formed by a presence of the cool air, and the gust front may result from a divergent flow with the cool air, due to the downward flow near the surface. Although a part of the divergent flow toward the rear region of the rainband B1 was not drawn from this observation, it may contribute to the evolution of the rainband B2.

\subsection{The region in the north-western side of the sur-} face cold front

Dynamical features obtained in the north-western side of the surface cold front are schematically shown in the panel (c3) of Fig. 20. In the right part of (c3) westerly and easterly winds dominate below and above the altitude of about $5 \mathrm{~km}$, respectively, and westerly wind appears again above the altitude of $8 \mathrm{~km}$. The precipitating clouds with the updraft regions seem to be restricted below the upper boundary of the cold frontal surface (roughly identified with reversal level between the middle-tropospheric easterly and the lower-tropospheric westerly winds). In the beginning of ascent of the cold frontal surface, rotor circulation occurs in the region between the upper-tropospheric westerly and middletropospheric easterly winds.

In the central and left parts of (c3), three layers with different wind directions were observed: i) in the region above the ascending cold frontal surface, ii) inside/under it, and iii) in the region with dry air and no precipitation particles below the frontal surface. In i) ascending easterly (south-easterly) winds are increased at the upper troposphere. In ii) north-westerly wind appears and the lower limit is almost coincident with the bright band level. A similar structure of the frontal surface descending 


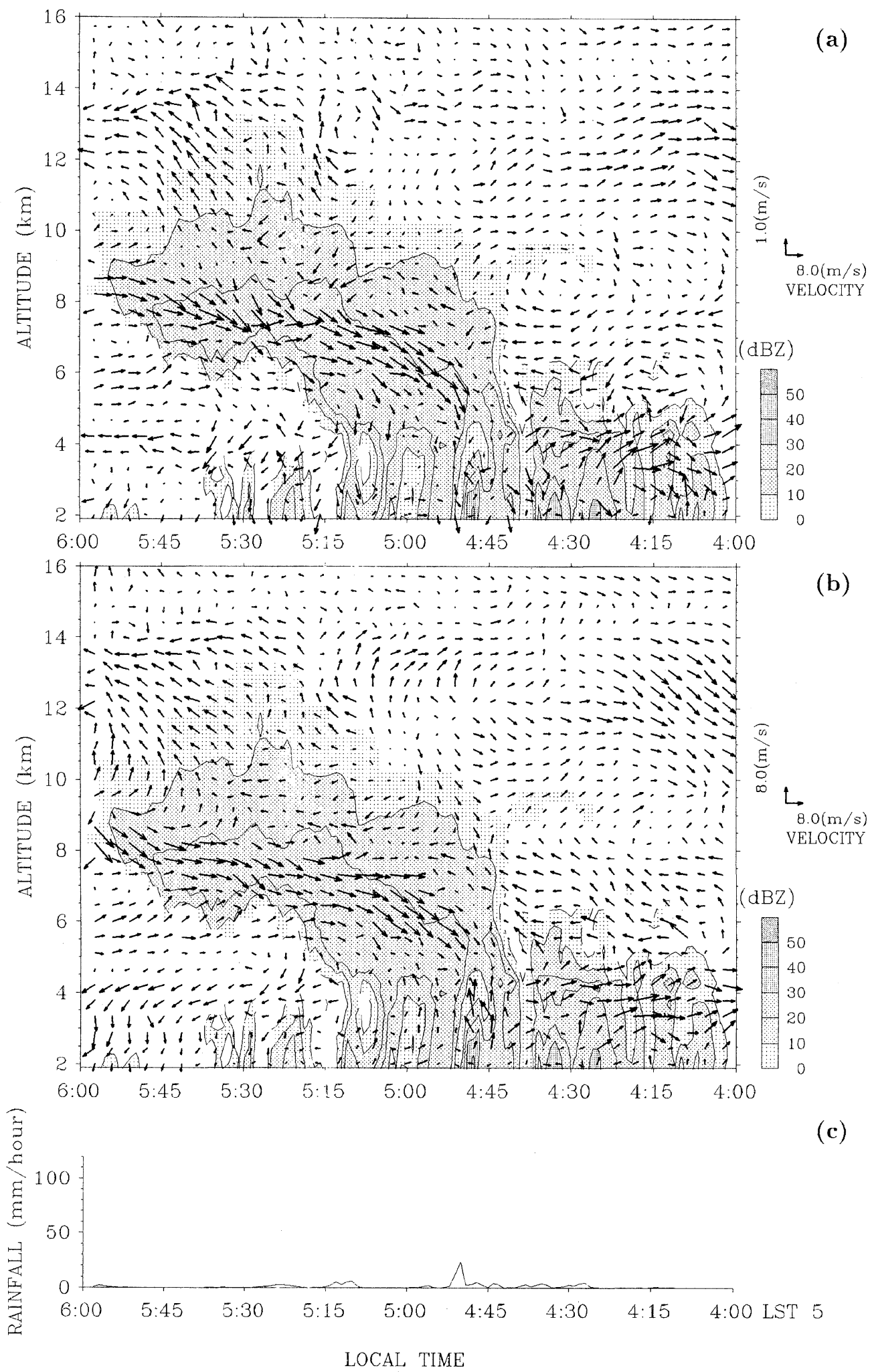

Fig. 18. Same as Fig. 13, but between 0400-0600 LST 5 July. The data intervals of RASC C-band radar are $1 \mathrm{~min}$. The MU data are linearly interpolated for the missing data as using in Fig. 8. 


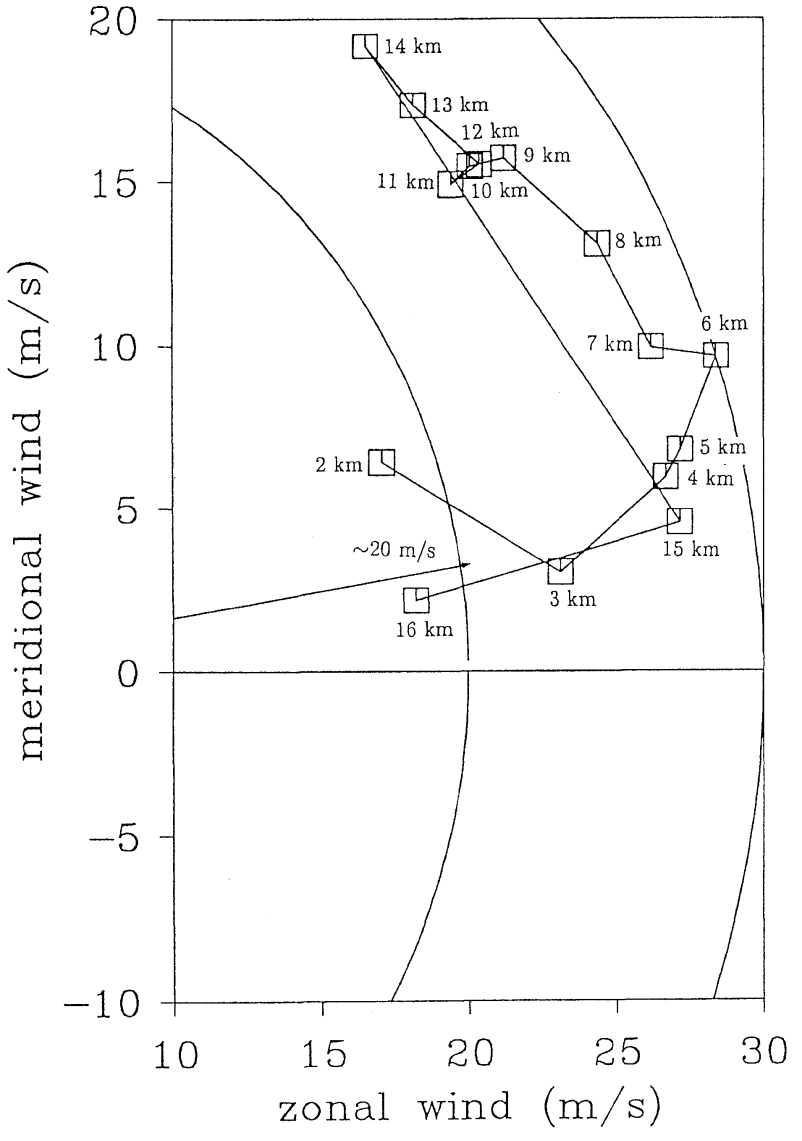

Fig. 19. Same as Fig. 7, but between 0400-0600 LST 5 July.

southward is also confirmed by the RHI plane of the X-band radar (not shown here). Upward and downward motions appear above and inside/under the cold frontal surface, respectively. The behaviors of the vertical motion must be characterized by mesoscale phenomena rather than larger-scale ones due to baroclinic instability. The upward velocity associated with southerly wind may have contributed to the growth of ice particles in the upper levels, whereas the downward velocity associated with the northerly wind may be related to the well-observed rear inflow inside stratiform portion toward the convective system (as corresponding to the two rainbands of B1 and B2) in the squall line. In iii) north-westerly flow descending along the cold frontal surface is returning toward the western side of the surface cold front. The features appearing in i)-iii) are similar to those behind a narrow cold-frontal rainband in western Europe studied by Browning and Harrold (1970).

\section{Conclusions}

By using VHF-, C- and X-band radars simultaneously, we could investigate structures of meso- $\beta$ and $-\gamma$-scale precipitating clouds near a meso- $\alpha$-scale cyclone on the Baiu front. We have investigated the meso- $\beta$ and $-\gamma$-scale wind circulation systems sub- tracted from the flow field associated with the meso$\alpha$-scale cyclone, for the three regions: i) near the surface warm front, ii) near the surface cold front and iii) on the north-western side of the surface cold front.

The cases of i) and ii) were characterized by typical convective cloud systems. The former was accompanied by convergence of zonal wind at the altitude range of $4-5 \mathrm{~km}$ and strong southerly wind in the middle troposphere. The convection appeared in the middle troposphere, and it was different from the structure extending from the lower troposphere as the convection cell inside the squall line in the midlatitude and as the warm sector rainband in the extratropical cyclone. The latter was identified with the shallow rainband with the gust front. Two rotor circulations were found in front of and inside the rainband, respectively. In the case of iii), threelayer structures with different wind directions were observed inside the stratiform cloud system. The dynamical structure was quite similar to that behind the cold-frontal rainband observed near the extratropical cyclone in western Europe.

In this study, vertical structures of the meso- $\beta$ and $-\gamma$-scale precipitating clouds with characteristic wind flows as mentioned above were revealed by the detailed three components of wind field in both clear and precipitating atmosphere. They were presented as smaller cloud systems in the hierarchical structure of cloud clusters near the meso- $\alpha$-scale cyclone in the central region of the Japan Islands.

As the next step of this study we will plan to observe both the horizontal distributions and temporal modifications of meso- $\beta$ and $-\gamma$-scale disturbances near the Baiu front with some smaller transportable radars (e.g., L- and S-band boundary layer radars; cf. Hashiguchi et al. 1995a, b).

\section{Acknowledgments}

We thank the Osaka District Meteorological Observatory for providing the C-band meteorological radar data. We also thank Dr. M. Murakami and anonymous reviewers for revising the manuscript. Thanks are extended to Dr. K. Kato and Professor K. Ninomiya for their constructive comments on a previous paper (Shibagaki et al. 1997) of this threeweek observation, many of which were also useful to describe this paper.

The MU radar belongs to, and is operated by, the Radio Atmosphere Science Center, Kyoto University. The first author (Shibagaki) was supported by a grant of the Japan Society for the Promotion of Science (JSPS) under the Fellowships for Japanese Junior Scientists. A part of the present study was also financially supported by Grants-inAids (03352012, 07640573) of the Japanese Ministry of Education, Sport, Science and Culture. 


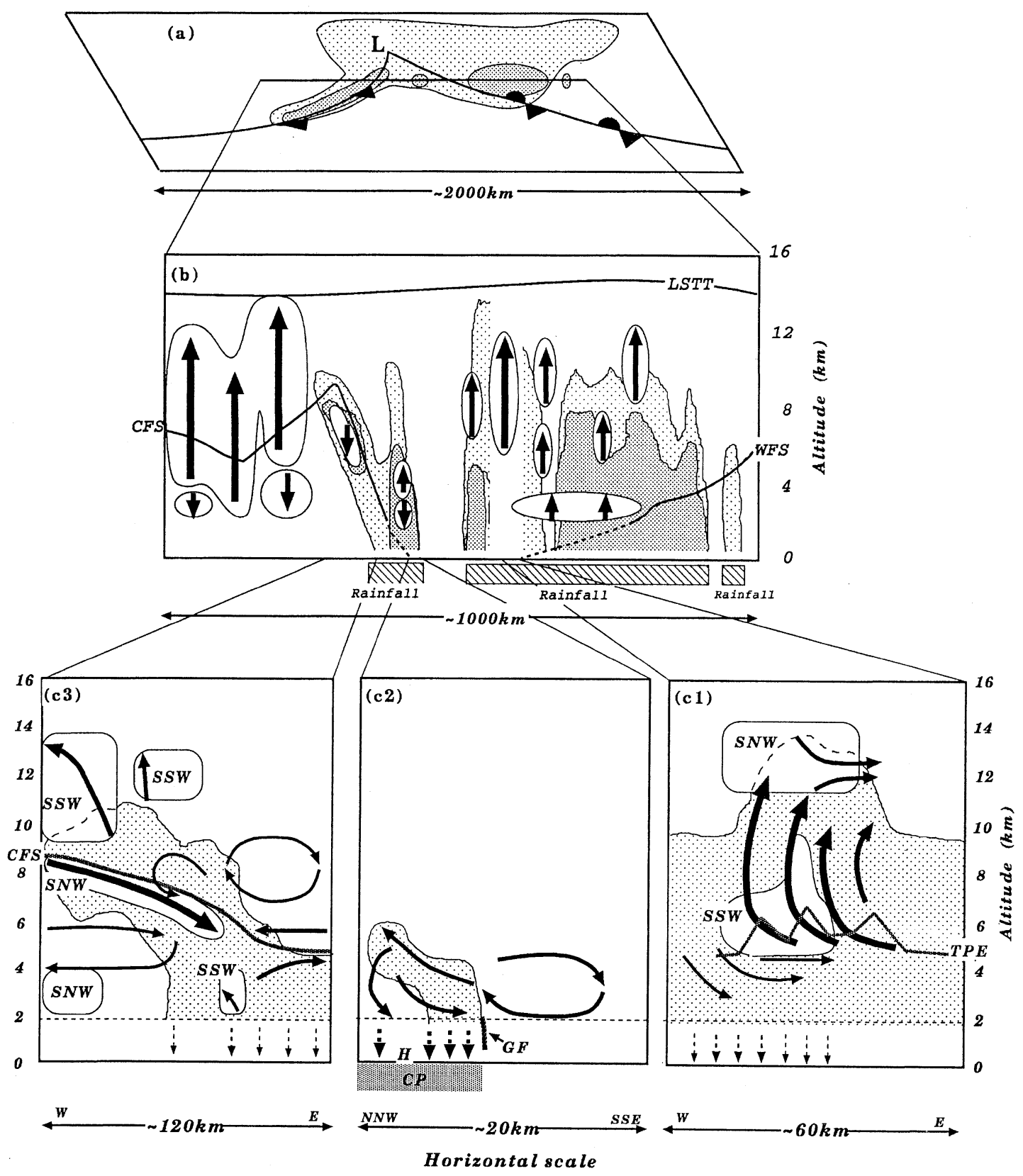

Fig. 20. Schematic illustration in (a) horizontal distribution of cloud clusters near the meso- $\alpha$-scale cyclone, (b) vertical distribution of vertical velocity fluctuations and precipitating clouds, and (c) meso- $\beta$ and $-\gamma$-scale wind circulation system in three regions; (c1) near the surface warm front, (c2) near the surface cold front and (c3) on the north-western side of the surface cold front. In panels (a) and (b) stippling indicates the region of weak precipitating echoes, and darker stippling represents the region of strong precipitating echoes. In panel (b) LSTT (the level of lowest stratiform turbulence near the tropopause level) is the tropopause level decided by the MU radar (see Shibagaki et al. (1997) for details). Solid lines of WFS and CFS are the upper boundaries of the warm and cold frontal surface, respectively. Arrows and contours are distributions of vertical motion observed by the MU radar and vertical precipitating cloud obtained by the the RASC C-band radar, respectively. In panel (c) solid curves are streamflow of horizontal-vertical component relative to the background wind for the direction shown in the bottom of each figure. Broken downward arrows are rainfall on the surface. Broken lines are the lowest altitude that the MU radar can observe. Characters of SSW and SNW in the white region are strong southerly and northerly winds, respectively. In (c1) contours are the cloud top estimating from the vertical echo intensity of the MU radar, and in (c2) and (c3) they are the precipitation echoes from the RASC C-band radar. Solid line of TPE in (c1) is the top level of the solid precipitation particle echoes observed by the MU radar. Characters of $\mathbf{G F}, \mathbf{H}$ and $\mathbf{C P}$ in (c2) indicate the gust front, the meso high and cold pool regions, respectively. 


\section{References}

Akiyama, T., 1984: A medium-scale cloud cluster in a Baiu front Part I: Evolution process and fine structure, J. Meteor. Soc. Japan, 62, 485-503.

Asai, T., 1990: A study of mechanism and prediction of heavy rainfalls during rainy season in Japan. Ocean Research Institute, Univ. of Tokyo, 458pp. (in Japanses).

Browning, K.A. and T.W. Harrold, 1970: Air motion and precipitation growth at a cold front. Quart. J. Roy. Meteor. Soc., 96, 369-389.

Fukao, S., K. Wakasugi, T. Sato, T. Tsuda, I. Kimura, N. Takeuchi, M. Matsuo and S. Kato, 1985a: Simultaneous observation of precipitating atmosphere by $\mathrm{VHF}$ band and $\mathrm{C} / \mathrm{Ku}$ band radars. Radio Sci., 20, 622-630.

—, T. Sato, T. Tsuda, S. Kato, K. Wakasugi and T. Makihira, 1985b: The MU radar with an active phased array system, 1 . Antenna and power amplifiers. Radio Sci., 20, 1155-1168.

- , T. Tsuda, T. Sato, S. Kato, K. Wakasugi and T. Makihira, 1985c: The MU radar with an active phased array system, 2. In-house equipment. Radio Sci., 20, 1169-1176.

- T. Sato, T. Tsuda, M. Yamamoto, M.D. Yamanaka and S. Kato, 1990: MU radar: New capabilities and system calibrations. Radio Sci., 25, $477-485$.

- M.F. Larsen, M.D. Yamanaka, H. Fukukawa, T. Tsuda and S. Kato, 1991: Observations a reversal in long-term average vertical velocities near the jet stream wind maximum. Mon. Wea. Rev., 119, 14791489.

Gage, K.S., 1990: Radar observations of the free atmosphere: Structure and dynamics, In Radar in $\mathrm{Me}$ teorology: Battan Memorial and 40th Anniversary Radar Meteorology Conference, D. Atlas, ed., American Meteorological Society in Boston, 534-565.

Gossard, E.E., 1979: A fresh look at the radar reflectively of clouds. Radio Sci., 14, 1089-1097.

Hashiguchi, H., M.D. Yamanaka, T. Tsuda, M. Yamamoto, T. Nakamura, T. Adachi, S. Fukao, T. Sato and D.L. Tobing, 1995a: Diurnal variations of the planetary boundary layer observed with an Lband clear-air Doppler radar. Bound. Layer Meteor., 74, 419-424.

, S. Fukao, T. Tsuda, M.D. Yamanaka, D.L. Tobing, T. Sribimawati, S.W.B. Harijono and H. Wiryosumarto, 1995b: Observations of the planetary boundary layer over equatorial Indonesia with an Lband clear-air Doppler radar: Initial result. Radio Sci., 30, 1043-1054.

Hobbs, V.P., K.R. Matejika and P.H. Herzegh, 1980: The mesoscale and microscale structure and organization of clouds and precipitation in mid-latitude cyclones. Part I: A case study of a cold front. J. Atmos. Sci., 37, 568-596.

Houze, R.A., Jr., S.A. Rutledge, M.I. Biggerstaff and B.F. Smull, 1989: Interpretation of Doppler weather radar displays of midlatitude mesoscale convective systems. Bull. Amer. Meteor. Soc., 70, 608-619.
Ishihara, M., Y. Fujiyosi, A. Tabata, H. Sakakibara, K. Akaeda and H. Okamura, 1995: Dual Doppler radar analysis of an intense mesoscale rainband generated along the Baiu front in 1988: Its kinematical structure and maintenance process. J. Meteor. Soc. Japan, 73, 139-163.

Iwasaki, H. and T. Takeda, 1989: Behavior of cumulonimbus-cloud groups in a slow-moving mesoscale cloud cluster over the ocean. J. Meteor. Soc. Japan, 67, 575-586.

Maddox, R.A., 1980: Mesoscale convective complexes. Bull. Amer. Meteorol. Soc., 61, 1374-1387.

Ninomiya, K. and T. Akiyama, 1992: Multi-scale features of Baiu, the summer monsoon over Japan and the East Asia. J. Meteor. Soc. Japan, 70, 467-495.

- M. Ikawa and T. Akiyama, 1981: Long-lived medium-scale cumulonimbus cluster in Asian subtropical humid region. J. Meteor. Soc. Japan, 59, $564-577$.

- , T. Akiyama and M. Ikawa, 1988a: Evolution and fine structure of a long-lived meso- $\alpha$-scale convective system in Baiu frontal zone. Part I: Evolution and meso- $\beta$-scale characteristics. J. Meteor. Soc. Japan, 66, 331-350.

- T. Akiyama and M. Ikawa, 1988b: Evolution and fine structure of a long-lived meso- $\alpha$-scale convective system in Baiu frontal zone. Part II: Meso- $\gamma$ scale characteristics of precipitation. J. Meteor. Soc. Japan, 66, 351-371.

Ogura, Y., T. Asai and K. Dohi, 1985: A case study of a heavy precipitation event along the Baiu front in northern Kyushu, 23 July 1982: Nagasaki heavy rainfall. J. Meteor. Soc. Japan, 63, 883-900.

Röttger, J. and M.F. Larsen, 1990: UHF/VHF radar techniques for atmospheric research and wind profiler applications, In Radar in Meteorology: Battan Memorial and 40th Anniversary Radar Meteorology Conference, D. Atlas, ed., American Meteorological Society in Boston, 235-281.

Sato, T., H. Iwai, I. Kimura, S. Fukao, M. Yamamoto, T. Tsuda and S. Kato, 1990: Computer processing for deriving drop-size distributions and vertical air velocities from VHF Doppler radar spectra. Radio Sci., 25, 961-973.

Shibagaki, Y., M.D. Yamanaka, H. Uyeda, A. Watanabe, Y. Maekawa and S. Fukao, 1996: Hierarchical structures of medium-scale cyclones and cloud clusters near the Baiu front observed by MU and meteorological radars: Outline and preliminary results of threeweek observation campaign. J. Geomag. Geoelectr., 48, 151-160.

, H. Hashiguchi, A. Watanabe, H Uyeda, Y. Maekawa and S. Fukao, 1997: Hierarchical structures of vertical velocity variations near the Baiu front observed by the MU radar. J. Meteor. Soc. Japan, 75, 569-596.

Smull, F.B. and R.A. Houze, Jr., 1985: A midlatitude squall line with a trailing region of stratiform rain, Radar and satellite observations. Mon. Wea. Rev., 113, 117-133.

and - 1987a: Dual-Doppler radar analysis of a midlatitude squall line with a trailing region of stratiform rain. J. Atmos. Sci., 44, 2128-2148. 
and - $1987 \mathrm{~b}$ : Rear inflow in squall lines with trailing stratiform precipitation. Mon. Wea. Rev., 115, 2869-2889.

Takahashi, N., H. Uyeda, S. Shimizu, Y. Asuma, K. Kikuchi, T. Harimaya, A. Watanabe and M.D. Yamanaka, 1995: Internal and meso- $\gamma$ scale structures of Baiu frontal rainbands observed at Shigaraki, Shiga prefecture by using a dual-polarization Doppler radar. Jour. Fac. Sci., Hokkaido Univ., Ser. VII (Geophysics), 9, 481-508.

- - - K. Kikuchi and K. Iwanami, 1996: Mesoscale and Convective Scale Features of Heavy Rainfall Events in Late Period of the Baiu Season in July 1988, Nagasaki Prefecture. Mon. Wea. Rev., 74, 539-561.

Yamanaka, M.D., S. Ogino, S. Kondo, T. Shimomai, S.
Fukao, Y. Shibagaki, Y. Maekawa and I. Takayabu, 1996: Inertio-gravity waves and subtropical multiple tropopause: Vertical wavenumber spectra of wind and temperature observed by the MU radar, radiosondes and operational rawinsonde network. $J$. Atmos. Terr. Phys., 58, 785-805.

Wakasugi, K., A. Mizutani, M. Matsuo, S. Fukao and S. Kato, 1986: A direct method for deriving dropsize distribution and vertical air velocities from VHF Doppler radar spectra. J. Atmos. Ocean. Tech., 3, 623-629.

and -1987

Further discussion on deriving drop-size distribution and vertical air velocities directly from VHF Doppler radar spectra. J. Atmos. Ocean. Tech., 4, 170-179. 
MUレーダーと気象レーダーによって観測された梅雨前線近傍の

降水雲に伴うメソ $\beta \sim \gamma$ スケール循環

\author{
柴垣佳明 \\ (大阪電気通信大学) \\ 山中大学 ${ }^{1}$ \\ (京都大学超高層電波研究センター) \\ 清水収司 ${ }^{2} \cdot$ 上田 博 \\ (北海道大学理学部) \\ 渡辺 明 \\ (福島大学教育学部) \\ 前川泰之 \\ (大阪電気通信大学) \\ 深尾昌一郎 \\ （京都大学超高層電波研究センター）
}

1991 年 6 月 17 日〜 7 月 8 日に $\mathrm{MU}(\mathrm{VHF}$ 帯 $) \cdot$ 気象 $(\mathrm{C} \cdot \mathrm{X} \cdot \mathrm{C} / \mathrm{Ku}$ 帯 $)$ レーダーを用いた梅雨季対流圈 の同時観測を行った。 $\mathrm{MU} \cdot \mathrm{C} / \mathrm{Ku}$ 帯レーダーは風速の 3 成分と雨雲の鉛直分布をそれぞれ観測した。ま た、 $\mathrm{C} \cdot \mathrm{X}$ 帯レーダーはメソ $\alpha$, メ $\beta$ スケールの雨雲の水平分布をそれぞれ調べた。この 3 週間の中で最

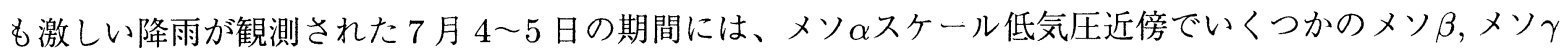
スケールの雲システムが観測された。これらはi) 温暖前線、ii) 寒冷前線付近の対流雲および iii) 寒冷前 線の北西側の層状雲として分類された。i) では、高度 $14 \mathrm{~km}$ 付近まで発達した降水雲内の顕著な上昇流 は高度 4 5 km に扔ける前面・後面からの吹き込み成分の収束と中部対流圈の強い南風によって生成さ れた。ii)では、寒冷前線の前面にガストフロントを持った狭いレインバンドがみられた。そのレインバ ンドの前方とその中では、メソ $\gamma$ スケールのローター循環がそれぞれ発見された。iii) では、南東風 (北西 風) は高度 $9 \mathrm{~km}$ 付近まで延びた寒冷前線面の上側に沿って (その内部および真下で) 上昇 (下降)してい た。その前線面下側には降雨を伴わない乾燥域が存在し、そこでは前線面に沿って下降した西風の一部が 雲システムの後方へ吹き出していた。本研究では、晴天・降雨域の両方で観測された詳細な風速 3 成分を

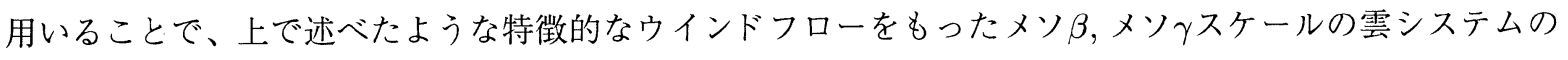
鉛直構造を明らかにした。これらの構造は日本中部で観測されたメソ $\alpha$ スケール低気圧近傍のクラウドク ラスターの階層構造の中のより小さな雲システムとして示された。 